\title{
Strategic Information System Planning in Healthcare Organizations
}

\author{
Theresa Lee, University of Toronto, Toronto, Canada \\ Amir Hossein Ghapanchi, School of Information and Communication Technology, Griffith \\ University, Southport, Queensland, Australia, and Institute for Integrated and Intelligent \\ Systems, Gold Coast, Queensland, Australia \\ Amir Talaei-Khoei, School of Systems, Management and Leadership, University of \\ Technology, Sydney, Australia \\ Pradeep Ray, Asia Pacific ubiquitous Healthcare Research Centre (APuHC), UNSW, Sydney, \\ Australia
}

\begin{abstract}
The healthcare industry is a critical and growing part of economies worldwide. To provide better quality of care, and value for money, billions of dollars are being spent on bettering information systems in healthcare organizations. Strategic Information System Planning (SISP) is instrumental in making informed decisions to achieve the health organizations'goals and objectives. This paper undertakes a systematic review to gain insight into existing studies on SISP in healthcare organizations. Our systematic review of papers on SISP from 1985 to 2011 examines the background and trend of research into SISP in the healthcare industry, classification of topics in SISP, as well as sets of tools and guidelines to aid practitioners and the research community alike.
\end{abstract}

Keywords: Healthcare Organizations, Strategic Information Systems Planning, Strategic Plan, Study Selection Process, Systematic Literature Review

\section{INTRODUCTION}

Healthcare is a critical social and economic component of modern economies. Healthcare spending accounts for a substantial portion of gross domestic product (GDP) in industrialized countries (OECD, 2011). Social, political and economic concerns, such as an aging population structure in industrialized nations, alongside rising costs of healthcare and healthcare technology, are resulting in pressures on cost-control as well as improved patient care. To deal with this pressing health policy issue, an increasing amount of attention is being paid to management practices of the healthcare industry to make informed decisions (Agarwal, Gao, DesRoches, 
\& Jha, 2010). In particular, information systems (IS) are being put in to place so that healthcare organizations and systems can be held accountable for these decisions (Jaana, Teitelbaum, \& Roffey, 2011; A. Winter et al., 2000). IS and Information Technology (IT) have become fundamental in the delivery of healthcare. IS investments in healthcare, have the potential to not only improve operational efficiency, but also service quality, patient satisfaction and quality of care (Bush, Lederer, Li, Palmisano, $\&$ Rao, 2009). As IS is looked upon as a key investment to addressing rising challenges of cost-control and quality improvement in the health care industry, use of IS in the healthcare industry has become an increasingly important and rapidly growing area of research.

The increasing role of IS and IT in healthcare is apparent in many geographic regions. In Europe, information and communication technology (ICT) for health is an emerging market estimated to be worth 60 billion Euros, and growing faster than all other health markets (European Commission \& Reding, 2009). Canada expects to spend CAD $\$ 10$ billion in the implementation of an electronic health record for all citizens (Canadian Institute for Health Information, 2009). In the United States alone, greater adoption of IS in healthcare could yield US $\$ 162$ billion per year in savings (R. Taylor et al., 2005). The growing body of literature on IS and IT in healthcare reveals that IS has much to offer in managing healthcare costs, improving the quality of care, making healthcare systems safer, more affordable and accessible (Agarwal et al., 2010; Chiasson \& Davidson, 2004; Fichman, Kohli, \& Krishnan, 2011). IS is uniquely positioned to capture, store, process and communicate timely information to decision makers to coordinate healthcare at both individual and population levels (Fichman et al., 2011). Significant increases in IT spending in recent years have generated growing interest in its effects on cost structure, healthcare quality, and patient privacy (Chiasson \& Davidson, 2004). Despite the potential benefits that IS can deliver to healthcare organizations, healthcare organizations face challenges in getting value from their IS investments. Effective use and beneficial outcomes from IS are not guaranteed and systems continue to fail to meet expectations in some way (Bush et al., 2009; Heeks, 2006).

The success of IS may depend on the extent to which healthcare organizations consider objectives and strategies in their information planning process (Bush et al., 2009). The definition of success for healthcare information systems has been a topic of interest in the research and practice community. Van der Meijden et al. (2003) have conducted a review and provided different items that need to be considered in definition of success; namely system quality; usage; user satisfaction; individual impact; organizational impact. Lau et al. (2010) have systematically looked at the factors influencing the success of information systems in healthcare settings. They indicated in-house system, developers as users, integrated decision support, benchmark practices; and also contextual issues such as provider knowledge $\&$ perception, incentives, legislation as concerns related to success of IS in healthcare settings. In addition to that, Paré et al. (2006) has indicated ownership as a strong driver for the success of clinical information systems. A way to identify objectives and strategies in the IS planning process is to use strategic information system planning (SISP). SISP is the process of identifying information systems that will assist a business in executing its organizational plans and realizing its business goals, to help information executives and top management identify strategic applications and align IT with organization needs (A. Winter et al., 2000). In coordination with an organization's business strategy and overall strategy, SISP can give directives for the construction and development of information systems, providing competitive advantage for the healthcare organizations (A. Winter et al., 2000).

Although SISP was introduced in the 1980s (Tähkäpää, Box, Turku, \& Tahkapaa, 2004; Yap, Platonova, \& Musa, 2006), the healthcare industry has lagged behind financial institutions, enterprises and other private industries, in adopting of formal strategies for IS planning 
(J.Adams, 2005; Yap et al., 2006). This lag may be partly due to the number of ways in which the healthcare industry differs from all other industries. First, health information systems are complex sociotechnical systems in comparison to other industries. Health information systems must represent a "patient", a complex abstraction of a person in comparison to a "customer" or "traveler" in banking industry or airline industry information systems (Beale, 2005). A person can be abstracted into eight levels of organizational complexity, from the cellular to the supersocietal, that are relevant in a health information system such as an electronic health record (EHR) (Beale, 2005). The innate complexity of a patient requires information systems such as EHRs to reflect multiple levels of biological and social organization of a person, account for mobile patients, record the entire life of a patient, abide by privacy laws, and adapt to constant changes of requirements, including new medical technologies, clinical procedures and guidelines, and genomic medicine (Beale, 2005). Furthermore, healthcare industry is motivated and organized differently from typical industrial settings of IS research, (e.g. for-profit industries including manufacturing, airlines, financial institutions and services) (Chiasson \& Davidson, 2004). Healthcare industries are highly institutionalized, in terms of professional roles and regulatory oversight. Healthcare regulation (Versel, 2010) particularly for privacy purposes makes healthcare organizations different than other industries. For instance, in many countries and specifically in the US the HITECH act not only requires information security but also requires efficient means for sharing patient information and hence it creates numerous state-regulated health information exchanges that build divergent compliance criteria for healthcare settings. Thus, healthcare organizations are operationally and technically complex (Chiasson \& Davidson, 2004). Unlike top-down hierarchical control structures found in many industries, healthcare field has a dual administrative structure of medical personnel and administration (Chiasson \& Davidson, 2004). The complexity of health care industry is compounded by a complex mixture of payment models (private, public, for-profit and not-for-profit), and varying levels of regulatory and market structures across regions (Chiasson \& Davidson, 2004). In addition, end user resistance (from clinicians) is a common occurrence, more so than other environments (B. Adams, Berner, \& Wyatt, 2004). Lastly, healthcare outputs are not only focused on measures of costs, profitability and customer satisfaction, but also societal values such as quality of life, absence of disease and public health (Chiasson $\&$ Davidson, 2004). The abovementioned complexities present in healthcare add challenges to adopting information systems compared to other industries.

According to Chiasson et al. (2004), research of IS specific to the healthcare industry may be of interest to IS scholars for two reasons. First, the healthcare industry poses important social challenges and research possibilities for researchers interested in development of IS and IT. IS researchers are interested in the development and application of IT as well as socioeconomic and organizational implication of IS and IT, the core of the research of IS in healthcare. Second, publications on IS in healthcare are bridging the two knowledge domains together and pushing IS research. By applying IS concepts that are traditionally developed in commercial industries into healthcare settings, studies demonstrate the relevance and meaning of IS research for healthcare. As the healthcare industry is markedly different from industries traditionally examined by IS researchers, hidden assumptions in IS theory could emerge from the healthcare context, thus pushing IS researchers to modify theory to be both more specific to the healthcare setting and also more general in order to encompass healthcare. Studies of IS in healthcare provides important opportunities to push IS theory by confronting theoretical assumptions embedded in current IS theory (Chiasson \& Davidson, 2004).

Although the healthcare domain has been underrepresented in leading IS journals (Chiasson \& Davidson, 2004; Fichman et al., 2011), interest in this topic is increasing. There are 
signs of growth in absolute numbers in literature which explore the range of theoretical approaches to diffusion and development of IS theory in healthcare settings (Chiasson \& Davidson, 2004). Furthermore, there are many opportunities to develop or test IS theories and assess their applicability in varied social contexts (Chiasson \& Davidson, 2004).

The main objective of this paper is to highlight the current and existing practices in developing SISP in healthcare settings. In order to narrow down the scope of our study, we consider the technicality and components of SISP as out of the scope for this work. In this paper, we examine more specifically the use of SISP in the healthcare sector. To date, there is limited information available in the literature on methodologies, frameworks and best practices of SISP in healthcare (Jaana et al., 2011). We document our findings from conducting a systematic review of current state-of-the-art research on SISP in healthcare organizations. This systematic approach helps us to determine where the literature has recurring themes, trends this stream of research has followed, and the gaps in the existing body of knowledge.

Throughout the paper we investigate the following questions:

1. What are demographic trends and implications for research on SISP for health?

2. What are various topics that have been covered in the literature?

3. What tools can be used for various tasks of SISP development in healthcare organizations?

4. What are some important guidelines for realizing SISP?

The current study identifies demographic trends in the research on SISP in the healthcare industry, and provides a summary of the literature. The topics of SISP are grouped by four categories: Development, Guidelines, Tools and Assessment. By updating work in this area and presenting the collection of tools, guidelines and steps for planning, implementing and assessing
SISP in the healthcare industry, this research seeks to help interested researchers as well as top management and IT personnel of healthcare organizations.

This paper is organized as follows. In the next section, we describe the method used for our systematic review. We then provide readers with answers to the research questions posed in the introduction, and the findings for the trend of studies on SISP in the healthcare industry, as well as the results of our synthesis of the literature. We propose a set of tools and guidelines for the realization of SISP in a healthcare. Following this, we provide a discussion of the paper and highlight implications for the research community as well as practitioners. We then conclude the paper, followed by the limitations of the study.

\section{METHOD}

This section describes the steps of the methodology used to perform the systematic review conducted in this study. A systematic literature review is a methodical way to identify, evaluate, and interpret the available empirical studies conducted on a topic, research question, or a phenomenon of interest (Kitchenham, 2004). Kitchenham(2004) considers three main phases for a systematic review including: Planning the review, Conducting the review, and Reporting on the review. This research follows the systematic review guidelines suggested by Kitchenham et al. (2004; 2009), as follows: (1) identify resources; (2) study selection; (3) data extraction; (4) data synthesis; and (5) write-up study as a report.

\section{Study Selection Process}

Figure 1 shows the stages of study selection for the systematic review in this paper using Kitchenham's guidelines (Kitchenham, 2004). The first stage involved searching 25 key words (see section entitled 'Search Terms') on 5 scientific databases (see section entitled 
Figure 1. Stages of the study selection process

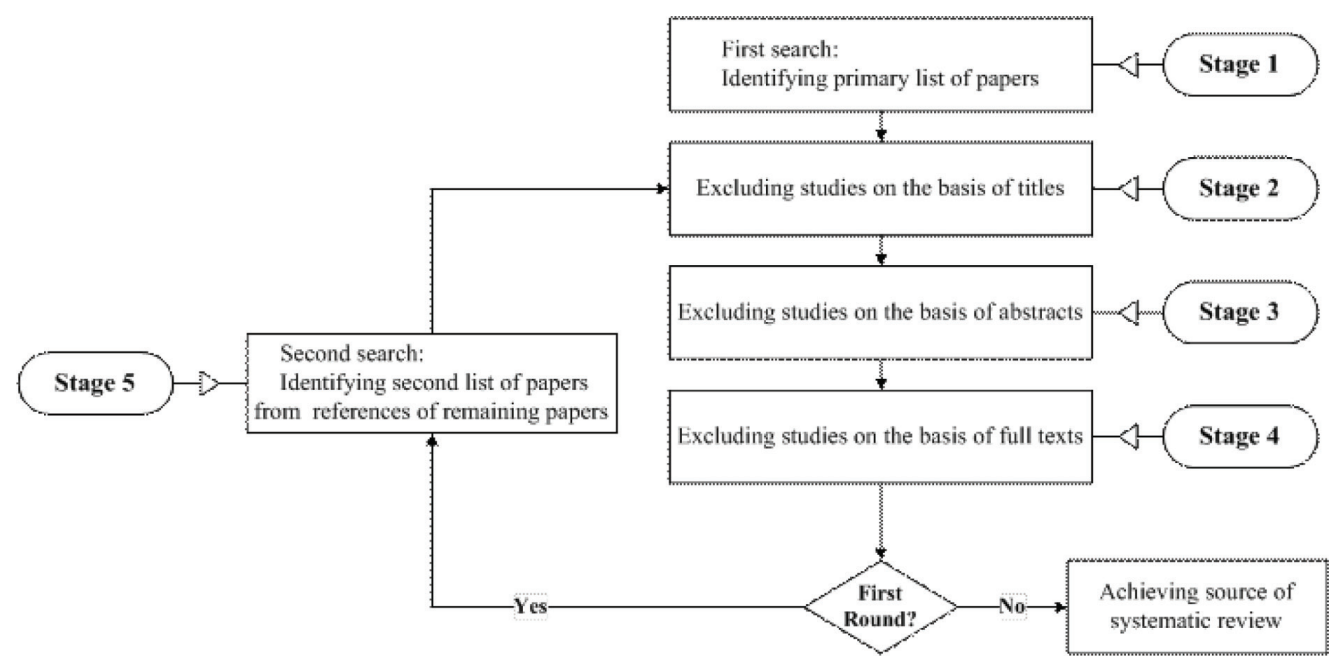

'Resources Used'). As a result, 1315 primary studies were identified.

\section{First Iteration}

In this iteration, we started with 1315 papers found on databases, and undertook stages 2, 3 , and 4; See Table 1. In stage 2, we excluded the studies on the basis of their titles (1056 papers were excluded in this stage; $n=259$ ). We excluded articles by their title when it was evident from the title that the article's topic was far removed from healthcare IS planning. When there was any doubt from the title whether the article was relevant to our search, the abstract was assessed. Stage 3 involved the exclusion of the papers on the basis of their abstracts (166 papers were excluded in this stage; $n=93$ ). In stage 4 , studies were excluded on the basis or relevance, online availability and language accessibility (45 papers were excluded in this stage; $n=48$ ). With the additional removal of 14 duplicate papers in multiple databases, we came up with 34 papers at the end of the first iteration. In order to increase the comprehensiveness of our search we went through all the references contained in the studies (899 papers) found in the first round, and undertook steps 2 to 4 for all of them.
We excluded articles by their title when it was evident from the title that the article's topic was far removed from healthcare IS planning. When there was any doubt from the title whether the article was relevant to our search, the abstract was assessed.

\section{Second Iteration}

In this iteration, we examined the 899 references contained in the 34 papers remaining at the end of iteration 1, and carried out stages 2, 3, and 4 again. First of all, stage 2 resulted in the exclusion of 862 papers based on their titles $(n=37$ papers remained). Afterwards 15 publications were excluded on the basis of their abstracts, resulting in 12 remaining papers. Finally, 5 papers were excluded based on their full-text - resulting in 7 relevant papers. Overall, the systematic review resulted in the identification of 41 relevant papers (34 in iteration 1 , and 7 in iteration 2). Table 2 provides the number of papers excluded in each iteration and stage.

\section{Resources Searched}

The following databases were used to search key words noted in the 'search terms' section: Scopus, PUBMED (including MEDLINE), ScienceDirect, Google scholar, and IEEE Explore. 
Table 1. Summary of paper extraction from databases

\begin{tabular}{|l|l|l|l|l|l|l|}
\hline \multicolumn{1}{|c|}{ Database Title } & $\begin{array}{c}\text { Search } \\
\text { Results Total }\end{array}$ & $\begin{array}{c}\text { Filtered } \\
\text { by Title }\end{array}$ & $\begin{array}{c}\text { Filtered by } \\
\text { Abstract }\end{array}$ & $\begin{array}{c}\text { Filtered } \\
\text { by Full } \\
\text { Text }\end{array}$ & Duplicates & Total \\
\hline Scopus & 280 & 164 & 20 & 15 & 3 & 12 \\
\hline Science Direct & 193 & 20 & 13 & 6 & 1 & 5 \\
\hline PUBMED & 622 & 43 & 38 & 18 & 4 & 14 \\
\hline IEEE Xplore & 92 & 10 & 8 & 4 & 4 & 0 \\
\hline Google Scholar & 128 & 22 & 14 & 5 & 2 & 3 \\
\hline First Iteration & 1315 & 259 & 93 & 48 & 14 & $\mathbf{3 4}$ \\
\hline Second Iteration & 899 & 862 & 15 & 5 & 0 & 7 \\
\hline Total & & & & & & $\mathbf{4 1}$ \\
\hline
\end{tabular}

\section{Search Terms}

In the first stage, depending on the search services offered by the relevant search engines, the titles, abstracts, keywords, and (in some cases) the full text of the journal articles and conference proceedings were searched using the following search terms:

- ("strategic plan" OR "strategic planning" OR "strategic information system planning" OR "strategic information system plan" OR "strategic information systems planning" OR "strategic information systems plan" OR "strategic information technology planning" OR "strategic information technology plan" OR "strategic information management planning" OR "strategic information management plan"); $A N D$

- ("informatics" OR "information system" OR “information technology" OR "information management" OR "software"); AND

- ("health"OR "health service providers" OR "hospital" OR "clinical” OR "clinic" OR "medicine" OR "medical" OR "biomedical" OR "healthcare" OR "health care").

Redundant search terms were used to optimize our search results and yield the most relevant articles. Although in theory it should

Table 2. Number of papers excluded in each iteration and stage

\begin{tabular}{|l|l|l|l|l|}
\hline Iteration & Initial Number of Papers & Stage of Exclusion & $\begin{array}{c}\text { Number of Papers } \\
\text { Excluded }\end{array}$ & $\begin{array}{c}\text { Number of Papers } \\
\text { Remaining }\end{array}$ \\
\hline $\mathbf{1}$ & \multirow{2}{*}{\begin{tabular}{l} 
(From databases) \\
\cline { 3 - 5 }
\end{tabular}} & Title & 1056 & $\mathbf{2 5 9}$ \\
\cline { 3 - 5 } & Abstract & 166 & $\mathbf{9 3}$ \\
\cline { 3 - 5 } & Full-Text & 45 & $\mathbf{4 8}$ \\
\cline { 3 - 5 } & Duplicates & 14 & $\mathbf{3 4}$ \\
\hline \multirow{2}{*}{$\mathbf{2}$} & $\begin{array}{l}899 \\
\text { (References of papers found } \\
\text { after iteration 1) }\end{array}$ & Title & 862 & $\mathbf{3 7}$ \\
\cline { 3 - 5 } & Abstract & 15 & $\mathbf{1 2}$ \\
\cline { 3 - 5 } & Full-Text & 5 & $\mathbf{7}$ \\
\hline \multicolumn{2}{|l|}{ Final number of papers: } & & & $\mathbf{4 1}$ \\
\hline
\end{tabular}


not make a difference, we noted that the number of search results varied with the inclusion of redundant terms. To err on the side of caution, we have used redundant search terms to extract a higher number of articles in such scenarios.

\section{Inclusion/Exclusion Criteria}

The selection of material for inclusion in our systematic review was based on the following inclusion and exclusion criteria. We included studies: (1) published between 1985 to 2011; (2) focused on Strategic Planning of Information Systems in the healthcare setting; and (3) that directly answered our research questions. We excluded studies: (1) inaccessible through online databases; (2) in languages other than English; (3) focusing on Strategic Planning in non-healthcare industry organizations; (4) where SISP procedure was not of the main focus; or (5) were in the form of overhead presentations, editorial notes, prefaces, article summaries, interviews, news, reviews, correspondence, discussions, comments, reader's letters and summaries of tutorials, workshops, panels, and poster sessions.

It should be noted that the main objective of this paper is to synthetize the SISP procedure, and it thus does not cover impact of the variable elements in the process. As such, in order to narrow down the search the fourth exclusion criteria are concerned with filtering the articles, which their main focus was not the procedure SISP.

\section{Data Extraction, Synthesis and Analysis}

The Data Extraction, Synthesis and Analysis stage involved the extraction of some key details from the 41 studies included in our systematic review. An analysis form was used (see the Appendix) to extract two types of data from the studies: (1) Demographics, to pick up year of publication, country, source name, research type and research methodology; and (2) Topics and Elements of SISP, to extract common factors involved in the realization of SISP in the healthcare industry in the literature.
For each publication, data were collected on the publication, originating country, source type (journal, book, conference paper, etc.), source name, research type, and research method. Next, the predominant topic of SISP was identified, and any process for the development and realization of SISP were represented in graphic or list form. Based on the topic of discussion in the 41 extracted publications, an initial list of 4 categories was identified. The papers included in the literature review could be categorized as (i) Development of SISP, (ii) Guideline for SISP, (iii) Assessment of SISP, or (iv) Tools for SISP.

These data were synthesized by grouping common themes and elements. Reviewing the methods and results for each publication revealed elements, stages and factors involved in the realization of SISP in the healthcare industry. The explanation and description of SISP used by the papers provided us with the results presented in the next section. Microsoft Excel was used for entering the data, undertaking descriptive analysis, and drawing diagrams.

\section{RESULTS}

\section{Demographic Trends}

Figure 2 depicts the distribution of the extracted papers per year. It shows that over the last 27 years there has been an increase in published papers covering Strategic Information Systems Planning in the healthcare industry. In particular, the number of papers has considerably increased since 1985, peaking in 2000 and 2005.

This might suggest the topic has grabbed the attention of academics as well as practitioners as a major concern for organizations. Although the increase in the number of studies since 1985 might not necessarily depict an increase in the implementation of SISP, it might be a good proxy indicator.

Figure 3 gives a breakdown of the frequency of the studies authored in different countries. The U.S. is the most dominant country with $57 \%$ of the authors affiliated with American organizations. Germany is the next most prolific source 
Figure 2. Frequency of publications in SISP in healthcare per year

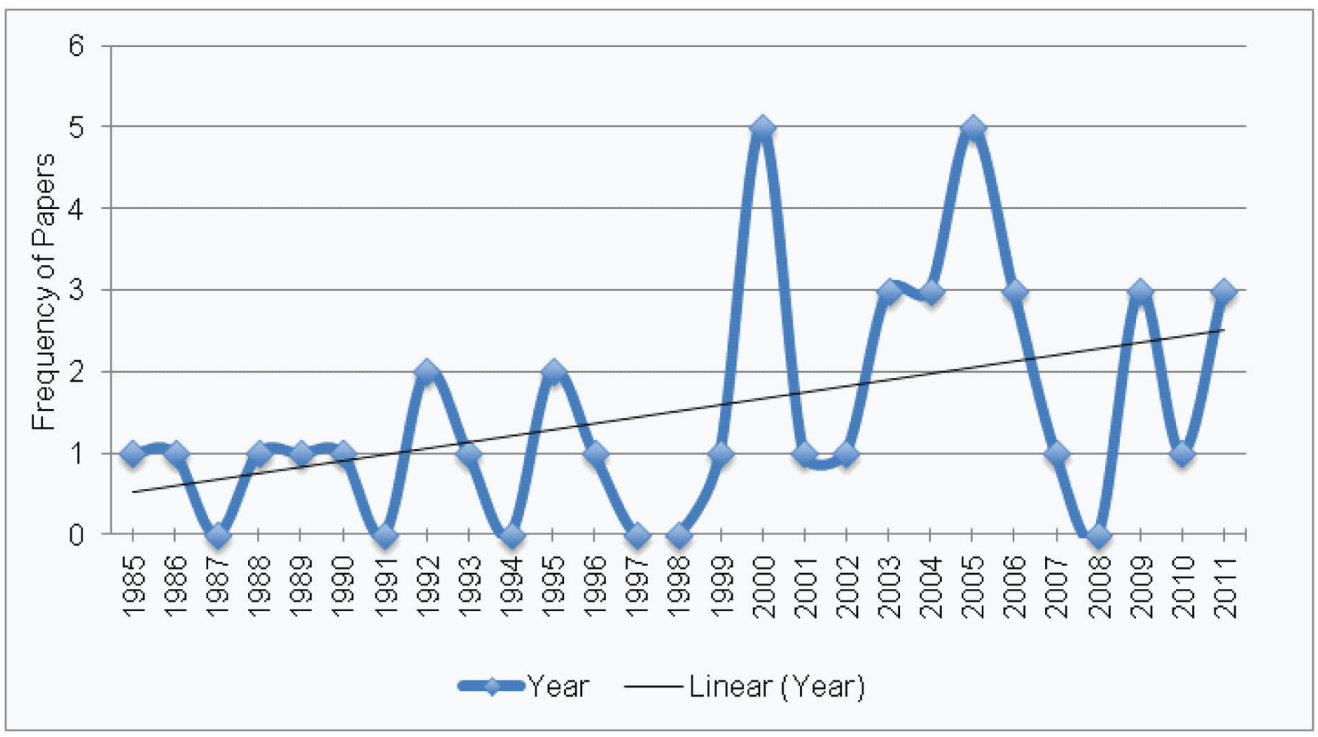

of country with $14 \%$ of the studies, followed by $5 \%$ of papers originating from each of Australia, Canada and New Zealand. It should be noted that only papers in English were included in the study, and published papers in other languages, notably Japanese, German and Scandinavian languages were excluded as per our Methods section. Of the publications included in the study, none originated from Asia (outside of the Middle East), South America or Africa.

The majority of these papers originated from the US ( 24 of 41 papers). This geographical distribution reflects the fact that the US produces the highest number of papers per year (Science Watch, 2009). In addition, this distribution may reflect the market-oriented nature of the US healthcare system, as opposed to socialized medicine in other countries with lesser number of publications. However, the vast majority $(88 \%)$ of the papers originating from countries outside the US with socialized medicine have been published post-2000, indicating the presence of SISP in these countries is current.

Figure 4 shows the source of the documents included in the study. The papers originated from 28 different sources. The two largest sources were the Journal of Healthcare Information
Management, and the Hawaii International Conference on System Sciences, each responsible for $10 \%$ of the total number of papers, while the International Journal of Medical Informatics was the next largest source at $8 \%$ of the papers.

Figure 5 illustrates the occurrence of different research approaches: Quantitative, Qualitative or Theoretical/Practical research types. The majority of the papers (28 papers, 67\%) were Qualitative Research types. Ten papers were in the theoretical/practical category, written from the experience of the authors without the illustration of a subject organization. Lastly, there were three quantitative research papers utilizing data from surveys or questionnaires. As shown in Figure 6, the majority of the papers were qualitative Case Studies of healthcare industry organizations $(61 \%)$. Other research methods included Survey (5\%), Audit Evaluation, Structured Interview, Literature Review, and a Consensus-based methodology.

\section{Topics of SISP in Health}

The papers included in the literature review could be classified into four different topics 
Figure 3. Frequency of publications in SISP in healthcare per country

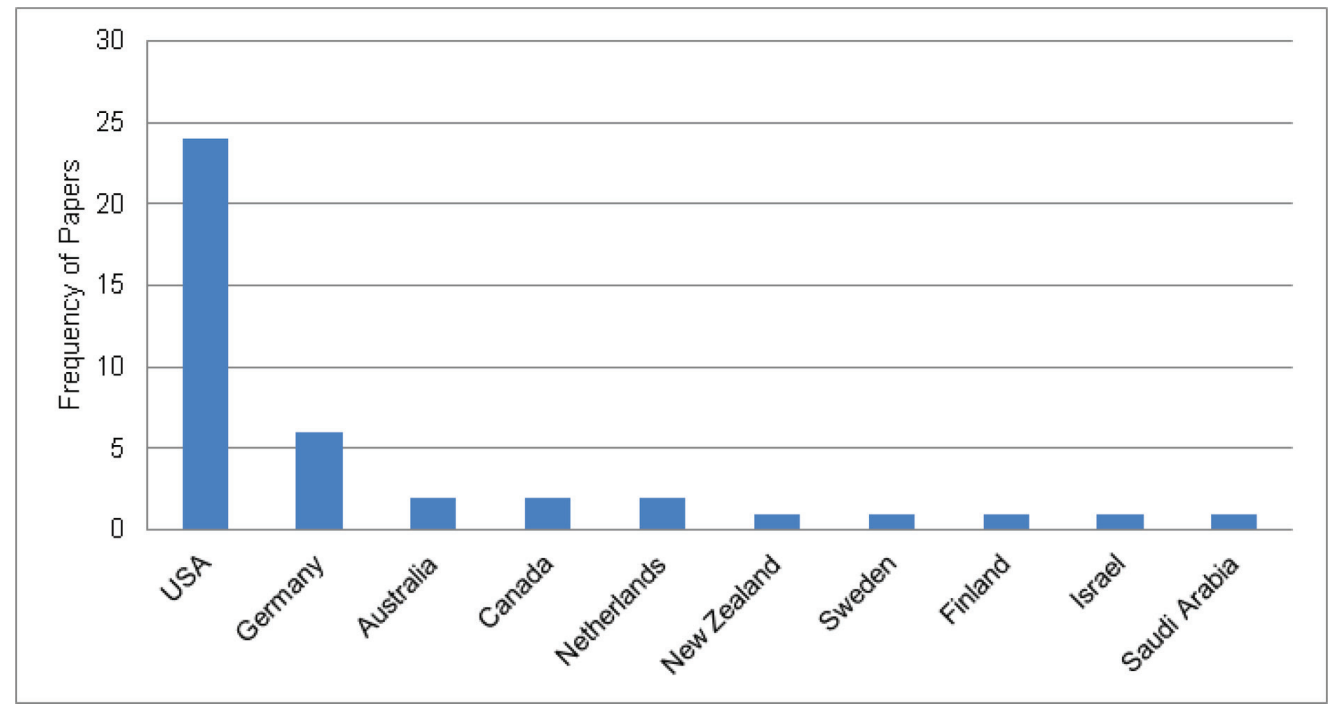

of SISP: Development of SISP, Guidelines for SISP, Assessment of SISP and Tool for SISP:

1. Development papers are case study papers that outline and describe the process of developing a SISP in a given health organization. These publications list the step-by-step process with which the subject organization implemented SISP, providing the framework and structure of the plan, justification for actions, lessons learned and recommendations for others. For instance, Frey et al. (2005) depicted the experience of implementing SISP in a Mayo Clinic in Arizona, USA, describing the need for SISP, planning process, implementation and final outcomes;

2. Guideline papers provided a set of steps and recommendations in proceeding with SISP in the healthcare setting, stressing the importance of certain factors in the successful IS planning in the healthcare setting. However, guideline papers did not put forward specific organizations as illustrations in the paper. Winter et al. (2001) introduced concept of SISP, described its purpose and importance, providing clear definitions of Strategic Information Management terms and how it can be used to aid practitioners, without explicit examples of specific organizations. Experienced practitioners such as Adams (2005) identified challenges facing organizations in SISP, such as end-user resistance, as well as a set of recommendations to overcome them;

3. Assessment Papers studied the past use of SISP in different settings and discussed and evaluated its findings. Papers discussed possible factors for successes and failures of certain SISP, and provided recommendation accordingly to achieve success or prevent failures (Gauld, 2007; Iacovou, 1999). Other papers discussed the degree to which SISP was effective for the organization (Belkin \& Corbitt, 2009), and also the prevalence of SISP within different organizations (Austin, Hornberger, \& Shmerling, 2000; Yap et al., 2006);

4. Tool papers discussed strategies, theories or methods that could be applied in a step in the SISP life cycle. For example, the use of Balanced Score Cards was presented in Bricknall et al. (2007) for verifying the alignment between Information Systems 
Figure 4. Distribution of papers amongst different sources

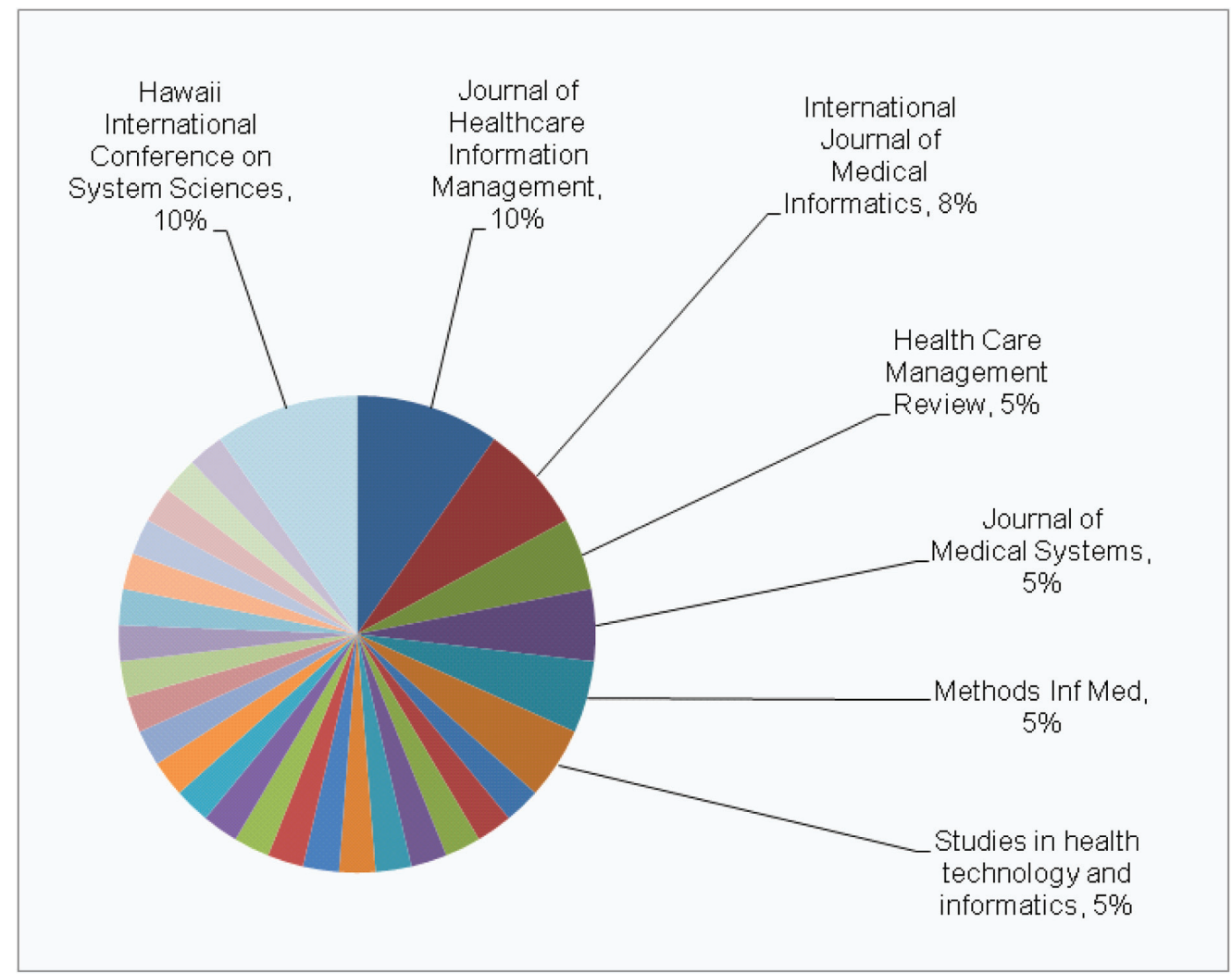

Plan and Business Plan of an organization. Such a tool can also be used for providing measurable objectives in creation of the plan (Hutsell \& Mancini-Newell, 2005; Mueller, Issler, Funkat, \& Winter, 2009).

The distribution of papers in each of the four topics is illustrated in Figures 7 and 8, and the list of papers in each topic of SISP is provided in Table 3. In the cases where a case study paper on development discussed any one or more of the other topics, the topic of Development took precedence in the categorization process.

\section{Tools for the Realization of SISP in Healthcare}

The literature on SISP provided a number of tools that can facilitate the SISP process. These tools are summarized in Table 4 and are sorted by the different stages of the SISP life cycle, thus where in the SISP process the tool can be used, what the tool entails, and lastly lists the source(s) from the literature. For instance, for the development stage, Jaana et al. (2011) recommends a tool to be effective in the preplanning process, which is to identify a table of contents of the Strategic IS Plan to create a clear idea of what needs to be completed by the end of the plan's development process. Still in the development stage, various tools are suggested for research, evaluation and envisioning of targets. For instance, the use of visual aids were recommended for describing the IT system to those involved in creating the SISP (Hutsell \& Mancini-Newell, 2005; Rosenberger \& Kaiser, 1985). In the implementation stage, Taylor (T. B. Taylor, 2004) recommends that 
Figure 5. Percentage of research types among the papers

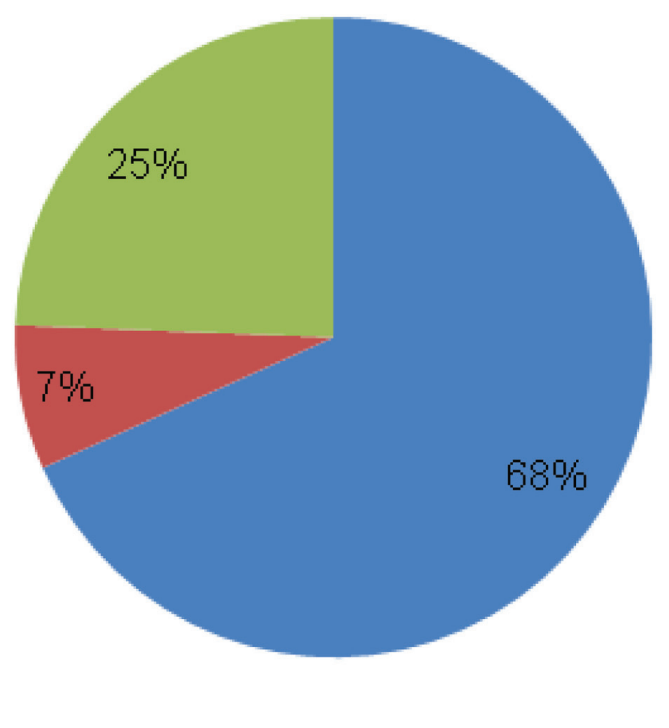

- Qualitative

- Quantitative

- Theoretical/Practical

Figure 6. Percentage of research methods used among the papers

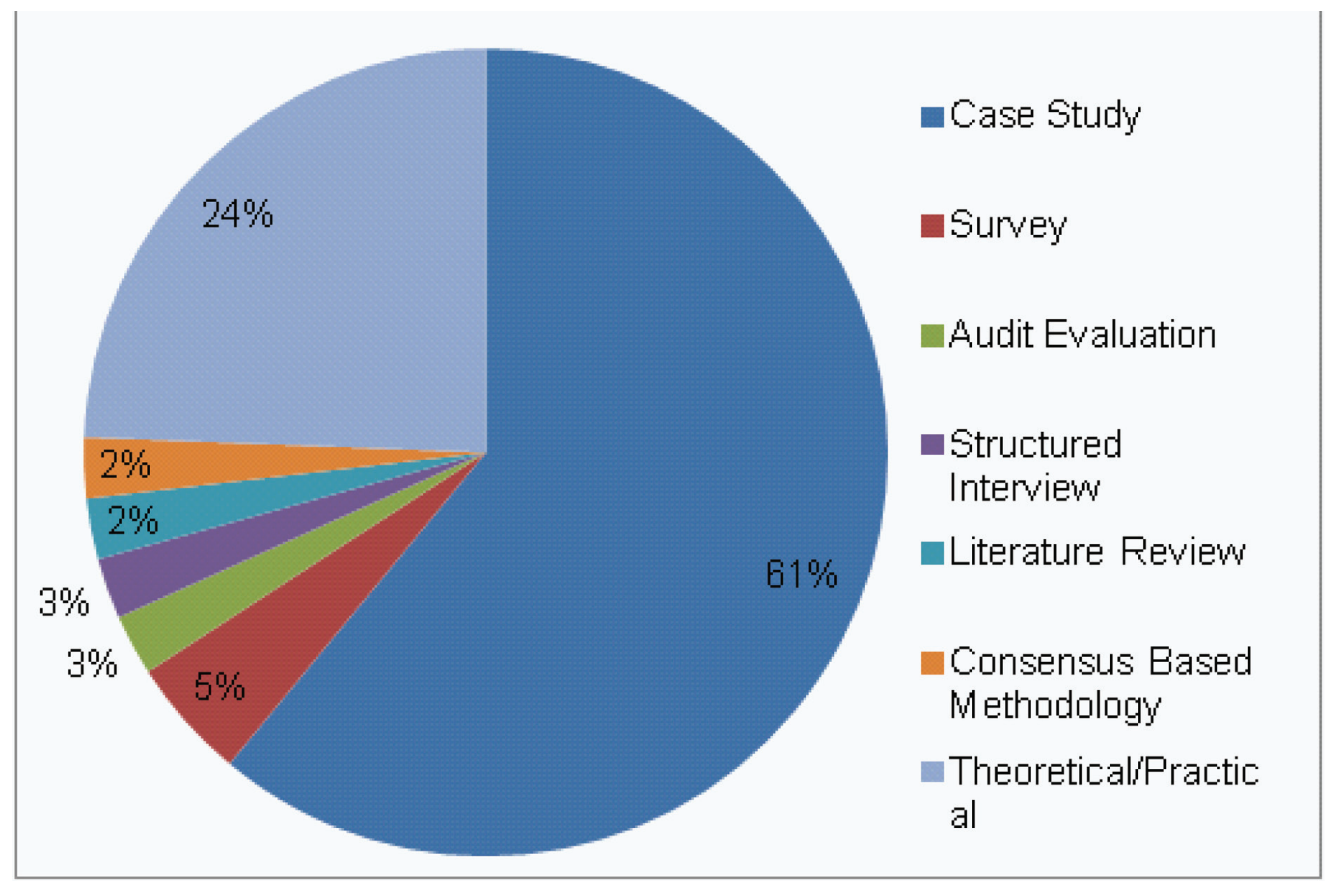


Figure 7. Percentage of papers in each topic of SISP

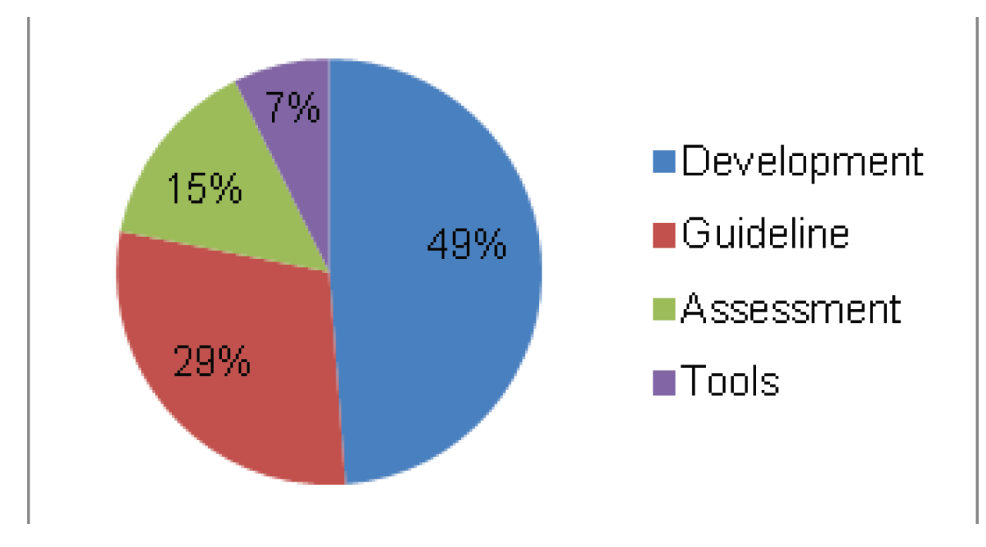

phase-in training be utilized in order to ease the transition and control the learning curve for the IS users. For the assessment stage, measurable objectives can provide a way of assessing the progress of the SISP (Hutsell \& ManciniNewell, 2005). At this stage, another tool is to engage stakeholders and staff by presenting the assessments in the form of annual report cards, satisfaction surveys, market share reports, and other quality and performance indicators (Urbanski et al., 2011). The tools listed in the table may be used in the indicated stage in the SISP lifecycle. Practitioners can use these tools to facilitate the process of SISP implementation. Walczak (2000) provides an interesting tool that engages with stockholders by developing workflow prototypes.

\section{General Guidelines for SISP in Health}

The literature provided some important guidelines for development, implementation and evaluation of SISP for healthcare organizations. These guidelines consisted of recommendations for achieving a successful SISP. The summary of tips and hints are presented in Table 5, along with an illustrative example from the literature and sources for each guideline. For instance, a number of authors (Bush et al., 2009; Hutsell \& Mancini-Newell, 2005) highlighted the importance of involvement and support of top management and executives of the organization in determining the success of SISP development. These recommendations include increasing the role of clinicians in the planning process, importance of clear communication, and considerations for the planning process, implementation process and future uncertainties.

\section{DISCUSSION}

\section{Implication for Researchers}

The current literature contains few papers that depict the overall picture of SISP in healthcare organizations. The papers in this study that included literature reviews noted the presence of research of SISP for organizations in nonhealthcare industries, but limited research in the context of hospitals or other healthcare settings. Overall, a shortage of empirical research for SISP in the healthcare setting was found (Jaana et al., 2011; Walker \& Houston, 2004). Further, majority of the available publications depict the experience of a limited number of individual organizations, offering recommendations from limited perspectives (Borovits et al., 1989; Frey et al., 2005; Jaana et al., 2011; A. F. Winter et al., 2001). To fill this gap, this current study aimed to gain a broader picture of what the literature has reported on SISP in healthcare.

This current study presents a set of tools and guidelines for researchers who wish to inves- 
Figure 8. Frequency of papers in each topic of SISP

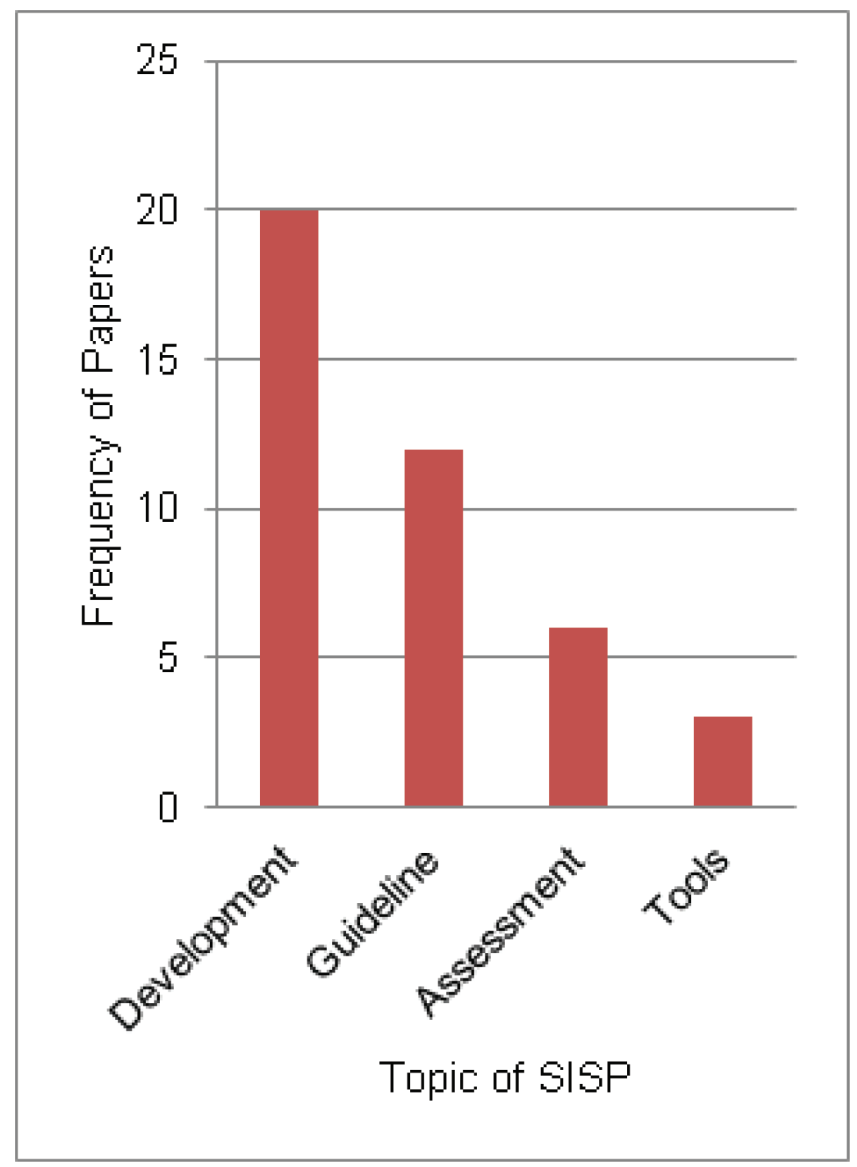

tigate SISP in other organizations. In addition, our analysis of demographic information and trends in the literature discussed in this study suggests four further gaps in the literature to be addressed by future studies:

1. Although there is a growing trend in the number of publications on the topic of SISP in healthcare, there is still a general lack of research being done in this area. This literature review pulled 41 papers over the course of 27 years from all major databases and search engines for healthcare research. It is crucial to investigate this industry further and share new findings and knowledge in order to establish best practices for adopting information systems; 2. The geographical distribution of the papers is highly skewed. The vast majority of publications were from US institutions, organizations and researchers, with only a handful from other countries outside of the US, notably northern Europe, Germany, Canada, and Australia. Research on SISP in other parts of the world might lead to insightful results. This paper calls on future research to conduct SISP in healthcare organizations in the all countries outside of the US, especially in the context of Asia, Africa and South America, and also to compare the use of SISP across various geographic locations; 
Table 3. Papers categorized by four topics of SISP

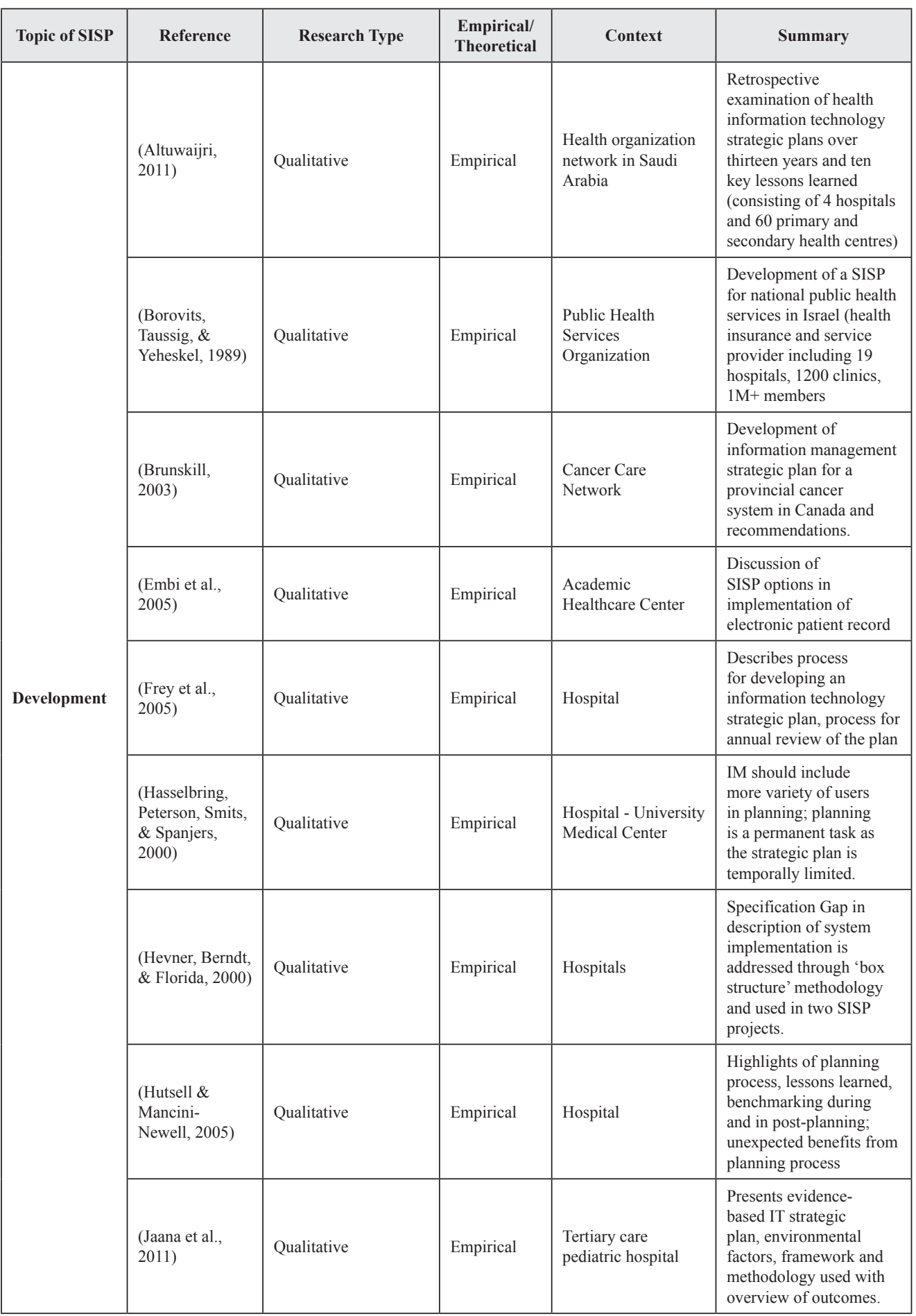


Table 3. Continued

\begin{tabular}{|c|c|c|c|c|c|}
\hline Topic of SISP & Reference & Research Type & $\begin{array}{l}\text { Empirical/ } \\
\text { Theoretical }\end{array}$ & Context & Summary \\
\hline \multirow{7}{*}{ Development } & $\begin{array}{l}\text { (Mueller et al., } \\
\text { 2009) }\end{array}$ & Qualitative & Empirical & Hospital & $\begin{array}{l}\text { Use of Interactive Plan } \\
\text { in strategic information } \\
\text { management plan -- } \\
\text { Nearly every employee } \\
\text { can see the goals' statuses } \\
\text { and the project data, } \\
\text { creating an incentive to } \\
\text { document a project's } \\
\text { progress promptly }\end{array}$ \\
\hline & $\begin{array}{l}\text { (Olsen \& Stead, } \\
1995)\end{array}$ & Qualitative & Empirical & $\begin{array}{l}\text { University Medical } \\
\text { Center }\end{array}$ & $\begin{array}{l}\text { Describes development } \\
\text { and use of a Deliverables } \\
\text { framework for planning } \\
\text { an Integrated Advanced } \\
\text { Information Management } \\
\text { System in a medical } \\
\text { centre. }\end{array}$ \\
\hline & (Smith, 1995) & Qualitative & Empirical & Hospitals & $\begin{array}{l}4 \text { methodologies } \\
\text { discussed for SISP in } \\
\text { health. Methodology is } \\
\text { less important than the } \\
\text { quality of the analysis, } \\
\text { which results and in this } \\
\text { sense the end-product is } \\
\text { more important than the } \\
\text { means by which it was } \\
\text { achieved. }\end{array}$ \\
\hline & $\begin{array}{l}\text { (Snyder-Halpern } \\
\text { \& Chervany, } \\
2000)\end{array}$ & Qualitative & Empirical & Hospital & $\begin{array}{l}\text { Describes linkages } \\
\text { among strategic } \\
\text { planning stages through } \\
\text { application of clinical } \\
\text { information system case } \\
\text { study }\end{array}$ \\
\hline & (Stead, 1988) & Qualitative & Empirical & $\begin{array}{l}\text { University Medical } \\
\text { Center - clinical } \\
\text { science department }\end{array}$ & $\begin{array}{l}\text { Integrated Academic } \\
\text { Information Management } \\
\text { System in University } \\
\text { Medical Center: } \\
\text { Proposal for a model } \\
\text { and assessment of an } \\
\text { information system } \\
\text { for a clinical science } \\
\text { department }\end{array}$ \\
\hline & $\begin{array}{l}\text { (Tähkäpää et al., } \\
\text { 2004) }\end{array}$ & Qualitative & Empirical & $\begin{array}{l}\text { Public healthcare } \\
\text { hospitals }\end{array}$ & $\begin{array}{l}\text { Management areas } \\
\text { to focus on for IS } \\
\text { development in a Finnish } \\
\text { public health care; } \\
\text { study of operational } \\
\text { environment and } \\
\text { stakeholders }\end{array}$ \\
\hline & (Tolchin, 1986) & Qualitative & Empirical & Hospital & $\begin{array}{l}\text { Describes approach to } \\
\text { systems development and } \\
\text { integration based on an } \\
\text { architectural plan }\end{array}$ \\
\hline
\end{tabular}


Table 3. Continued

\begin{tabular}{|c|c|c|c|c|c|}
\hline Topic of SISP & Reference & Research Type & $\begin{array}{l}\text { Empirical/ } \\
\text { Theoretical }\end{array}$ & Context & Summary \\
\hline \multirow{4}{*}{ Development } & $\begin{array}{l}\text { (Urbanski, } \\
\text { Baskel, \& } \\
\text { Martelli, 2011) }\end{array}$ & Qualitative & Empirical & Hospital & $\begin{array}{l}\text { Engagement of } \\
\text { stakeholders in } \\
\text { SISP through use of } \\
\text { measurable objectives, } \\
\text { Conversation Café, } \\
\text { Strategic Oversight } \\
\text { Teams, Champions, and } \\
\text { report cards. }\end{array}$ \\
\hline & $\begin{array}{l}\text { (Van De } \\
\text { Wetering, } \\
\text { Batenburg, } \\
\text { \& Lederman, } \\
\text { 2010) }\end{array}$ & Qualitative & Empirical & Hospital & $\begin{array}{l}\text { Strategic planning } \\
\text { proposed for a } \\
\text { picture archiving and } \\
\text { communication system } \\
\text { (PACS) deployment; } \\
\text { based on strategic } \\
\text { alignment concept, } \\
\text { maturity growth path } \\
\text { concept on the PACS } \\
\text { domain. }\end{array}$ \\
\hline & $\begin{array}{l}\text { (Walker \& } \\
\text { Houston, 2004) }\end{array}$ & Qualitative & Empirical & Military Hospital & $\begin{array}{l}\text { SISP of military health } \\
\text { care system, including } \\
\text { qualitative analysis of IS; } \\
\text { planning methodology; } \\
\text { recommendation of } \\
\text { information management } \\
\text { goals; alignment with } \\
\text { strategic goals and } \\
\text { objectives; resource } \\
\text { requirements. }\end{array}$ \\
\hline & $\begin{array}{l}\text { (A. Winter, } \\
\text { Brigl, \& Wendt, } \\
\text { 2003) }\end{array}$ & Qualitative & Empirical & Hospital & $\begin{array}{l}\text { Provides terminology/ } \\
\text { ontologies for } \\
\text { designating health } \\
\text { information systems } \\
\text { (HIS) and their } \\
\text { components as well } \\
\text { as describing a HIS } \\
\text { architecture by a multi- } \\
\text { layer model. (3LGM) }\end{array}$ \\
\hline \multirow[b]{2}{*}{ Guideline } & $\begin{array}{l}\text { (J. Adams, } \\
\text { 2005) }\end{array}$ & Theoretical/Practical & Theoretical & $\begin{array}{l}\text { Health care } \\
\text { organization in } \\
\text { general }\end{array}$ & $\begin{array}{l}\text { Guidelines on healthcare } \\
\text { strategy from industry } \\
\text { expert }\end{array}$ \\
\hline & $\begin{array}{l}\text { (Brigl et al., } \\
\text { 2005) }\end{array}$ & Qualitative & Empirical & $\begin{array}{l}\text { University and } \\
\text { regional hospital in } \\
\text { Germany }\end{array}$ & $\begin{array}{l}\text { Developing a } \\
\text { comprehensive structure } \\
\text { of systematic information } \\
\text { management plan and } \\
\text { adoption in a regional } \\
\text { hospital and two } \\
\text { university hospitals. }\end{array}$ \\
\hline
\end{tabular}


Table 3. Continued

\begin{tabular}{|c|c|c|c|c|c|}
\hline Topic of SISP & Reference & Research Type & $\begin{array}{l}\text { Empirical/ } \\
\text { Theoretical }\end{array}$ & Context & Summary \\
\hline \multirow{6}{*}{ Guideline } & $\begin{array}{l}\text { (Gunasekaran \& } \\
\text { Garets, 2003) }\end{array}$ & Theoretical/Practical & Theoretical & $\begin{array}{l}\text { Health care } \\
\text { organization in } \\
\text { general }\end{array}$ & $\begin{array}{l}\text { Provides framework for } \\
\text { IT strategic planning that } \\
\text { can be used not only to } \\
\text { align IT investments with } \\
\text { business objectives but } \\
\text { also to provide clarity to } \\
\text { enterprise business IT } \\
\text { strategy. }\end{array}$ \\
\hline & $\begin{array}{l}\text { (Henderson \& } \\
\text { Thomas, 1992) }\end{array}$ & Theoretical/Practical & Theoretical & Hospitals & $\begin{array}{l}\text { Development of a } \\
\text { framework for strategic } \\
\text { information technology } \\
\text { management in hospitals, } \\
\text { termed the Strategic } \\
\text { Alignment Model } \\
\text { (business strategy, IT } \\
\text { strategy, organizational } \\
\text { infrastructure, and IT } \\
\text { infrastructure) }\end{array}$ \\
\hline & $\begin{array}{l}\text { (Killingsworth, } \\
\text { Newkirk, \& } \\
\text { Seeman, 2006) }\end{array}$ & Theoretical/Practical & Theoretical & Hospital & $\begin{array}{l}\text { Development of } \\
\text { constructing a strategic } \\
\text { information system } \\
\text { development framework } \\
\text { flexible enough to } \\
\text { permit a hospital to } \\
\text { adjust its strategies to } \\
\text { environmental changes }\end{array}$ \\
\hline & (Moriarty, 1992) & Theoretical/Practical & Theoretical & Hospitals & $\begin{array}{l}\text { Presents key strategic } \\
\text { information systems } \\
\text { issues that allow health } \\
\text { care managers to } \\
\text { conceptualize its impact } \\
\text { and identify opportunities } \\
\text { for successful IT } \\
\text { implementation }\end{array}$ \\
\hline & (Ribka, 1996) & Theoretical/Practical & Theoretical & $\begin{array}{l}\text { Health care } \\
\text { organization in } \\
\text { general }\end{array}$ & $\begin{array}{l}\text { Identifies three distinct } \\
\text { functional areas } \\
\text { in which managed } \\
\text { care components } \\
\text { play a part (contract } \\
\text { management and billing } \\
\text { for the hospital; for } \\
\text { physicians; managed } \\
\text { care administration } \\
\text { and management of } \\
\text { contractual risk) }\end{array}$ \\
\hline & $\begin{array}{l}\text { (Rosenberger \& } \\
\text { Kaiser, 1985) }\end{array}$ & Qualitative & Empirical & $\begin{array}{l}\text { Private non-profit } \\
\text { health organization }\end{array}$ & $\begin{array}{l}\text { Dynamic framework } \\
\text { proposed for } \\
\text { management information } \\
\text { system and future } \\
\text { development for a } \\
\text { comprehensive care } \\
\text { program for patients with } \\
\text { hemophilia in Wisconsin }\end{array}$ \\
\hline
\end{tabular}

continued on following page 
Table 3. Continued

\begin{tabular}{|c|c|c|c|c|c|}
\hline Topic of SISP & Reference & Research Type & $\begin{array}{l}\text { Empirical/ } \\
\text { Theoretical }\end{array}$ & Context & Summary \\
\hline \multirow{4}{*}{ Guideline } & (Spitzer, 1993) & Theoretical/Practical & Theoretical & Hospital settings & $\begin{array}{l}\text { Comprehensive guideline } \\
\text { of SISP for CIOs }\end{array}$ \\
\hline & $\begin{array}{l}\text { (T. B. Taylor, } \\
\text { 2004) }\end{array}$ & Theoretical/Practical & Theoretical & $\begin{array}{l}\text { Emergency } \\
\text { Department of } \\
\text { Hospitals }\end{array}$ & $\begin{array}{l}\text { Recommendation } \\
\text { for implementing an } \\
\text { emergency department } \\
\text { information system }\end{array}$ \\
\hline & $\begin{array}{l}\text { (A. Winter et al., } \\
2000)\end{array}$ & Theoretical/Practical & Theoretical & Hospitals & $\begin{array}{l}\text { Describes purpose of } \\
\text { SISP suggests a structure } \\
\text { for SISP in hospitals }\end{array}$ \\
\hline & $\begin{array}{l}\text { (A. F. Winter et } \\
\text { al., 2001) }\end{array}$ & Theoretical/Practical & Theoretical & Hospitals & $\begin{array}{l}\text { Proposes a structure for } \\
\text { SISP }\end{array}$ \\
\hline \multirow{6}{*}{ Assessment } & $\begin{array}{l}\text { (Austin et al., } \\
2000 \text { ) }\end{array}$ & Quantitative & Empirical & $\begin{array}{l}10 \text { healthcare } \\
\text { organizations }\end{array}$ & $\begin{array}{l}\text { Audit of evaluation of } \\
\text { SISP for } 10 \text { organizations } \\
\text { (from small/rural to } \\
\text { large/urban hospitals and } \\
\text { teaching hospitals) }\end{array}$ \\
\hline & $\begin{array}{l}\text { (Belkin \& } \\
\text { Corbitt, 2009) }\end{array}$ & Mixed-methods & Empirical & $\begin{array}{l}\text { Pathology } \\
\text { Departments }\end{array}$ & $\begin{array}{l}\text { Evaluation of SISP } \\
\text { capability for pathology } \\
\text { laboratories in Australia; } \\
\text { factors critical to SISP } \\
\text { success }\end{array}$ \\
\hline & (Gauld, 2007) & Qualitative & Empirical & Hospital & $\begin{array}{l}\text { Characteristics lending to } \\
\text { failure of large hospital } \\
\text { IS project in New } \\
\text { Zealand }\end{array}$ \\
\hline & (Iacovou, 1999) & Qualitative & Empirical & $\begin{array}{l}\text { Teaching/Research } \\
\text { Hospital in Canada }\end{array}$ & $\begin{array}{l}\text { Case study of factors } \\
\text { leading to the failure } \\
\text { of implementing an } \\
\text { Integrated Patient } \\
\text { Administration and Care } \\
\text { System }\end{array}$ \\
\hline & $\begin{array}{l}\text { (Kim \& } \\
\text { Michelman, } \\
\text { 1990) }\end{array}$ & Qualitative & Empirical & Hospitals & $\begin{array}{l}\text { Identifies factors } \\
\text { for strategic use of } \\
\text { information systems } \\
\text { technology in healthcare; } \\
\text { Proposes methodology } \\
\text { for assessment and } \\
\text { develops a model for } \\
\text { examining role of IS in } \\
\text { healthcare. }\end{array}$ \\
\hline & $\begin{array}{l}\text { (Yap et al., } \\
2006 \text { ) }\end{array}$ & Quantitative & Empirical & Military Hospital & $\begin{array}{l}\text { Exploratory study to } \\
\text { assess effectiveness of } \\
\text { IS in supporting strategic } \\
\text { plan development in Air } \\
\text { Force medical treatment } \\
\text { facilities }\end{array}$ \\
\hline
\end{tabular}


Table 3. Continued

\begin{tabular}{|c|c|c|c|c|c|}
\hline Topic of SISP & Reference & Research Type & $\begin{array}{l}\text { Empirical/ } \\
\text { Theoretical }\end{array}$ & Context & Summary \\
\hline \multirow{4}{*}{ Tools } & $\begin{array}{l}\text { (Ammenwerth, } \\
\text { Buchauer, \& } \\
\text { Haux, 2002) }\end{array}$ & Qualitative & Empirical & $\begin{array}{l}\text { University hospitals } \\
\text { in Germany }\end{array}$ & $\begin{array}{l}\text { Development of a } \\
\text { requirements index } \\
\text { model for information } \\
\text { processing requirements } \\
\text { to support management } \\
\text { of health information } \\
\text { systems }\end{array}$ \\
\hline & $\begin{array}{l}\text { (Bricknall et al., } \\
\text { 2007) }\end{array}$ & Qualitative & Empirical & $\begin{array}{l}\text { Pharmaceutical } \\
\text { company }\end{array}$ & $\begin{array}{l}\text { Use of a Balanced } \\
\text { Score Card to align } \\
\text { business and IT strategies } \\
\text { methodologies. }\end{array}$ \\
\hline & $\begin{array}{l}\text { (Bush et al., } \\
\text { 2009) }\end{array}$ & Qualitative & Empirical & $\begin{array}{l}20 \text { health care } \\
\text { organizations in } \\
\text { mid-western US }\end{array}$ & $\begin{array}{l}\text { Study of use of } \\
\text { strategic alignment } \\
\text { for IT in healthcare, } \\
\text { identifies managerial } \\
\text { and organizational } \\
\text { characteristics that } \\
\text { enable or hinder strategic } \\
\text { alignment (including } \\
\text { homecare, mental health } \\
\text { institution, nursing } \\
\text { facility, acute care, } \\
\text { inpatient, outpatient care } \\
\text { centres) }\end{array}$ \\
\hline & (Walczak 2000) & Theoretical/Practical & Theoretical & Clinical offices & $\begin{array}{l}\text { This paper introduces } \\
\text { a Workflow re-design } \\
\text { tool with ability of } \\
\text { prototyping. }\end{array}$ \\
\hline
\end{tabular}

3. There was limited number of research methodologies used in investigating SISP in healthcare. The majority of the available research was qualitative in nature and utilized case study methods. Papers with a theoretical or practical basis were also included in this literature review; however, the existing research provides little evidence in quantitative form. This area of research could benefit from the translation of qualitative observations and tacit knowledge of experienced practitioners into quantitative form. Data comparable across different locations and papers may be worthy of examination in order to identify significant variables of successful SISPs;

4. Finally, there is a lack of papers quantifying the effectiveness of SISP in healthcare, and assessing different tools to achieve SISP. The majority of the papers discussed the development of SISP in specific organizational settings, or provided a summary and guideline for other practitioners. Although there are a number of papers proposing generic processes for SISP development and its implementation, there is a shortage of papers on the topic of SISP assessment and SISP tools, and no research that consolidates guidelines and in all areas of SISP in a healthcare setting.

\section{Implications for Practitioners}

This review of literature provides several recommendations and considerations for IS practitioners of the healthcare sector. The authors conducted a systematic literature review to (i) identify demographic trends, (ii) identify topics of SISP covered in the literature, (iii) assemble a set of tools to develop, implement and assess the 
Table 4. Tools for different stages of SISP

\begin{tabular}{|c|c|c|}
\hline Stage of SISP & Description & References \\
\hline \multicolumn{3}{|l|}{ Development } \\
\hline Pre-planning & Create a table of contents of the plan prior to planning process & $\begin{array}{l}\text { (Brigl et al., 2005; Jaana et al., } \\
\text { 2011) }\end{array}$ \\
\hline \multirow{8}{*}{$\begin{array}{l}\text { Research, Evaluation, } \\
\text { envisioning targets }\end{array}$} & $\begin{array}{l}\text { Interview with set of questions } \\
\text { - Leader of departments and domains } \\
\text { - User of IS } \\
\text { - Stakeholders }\end{array}$ & $\begin{array}{l}\text { (Frey et al., 2005; Jaana et al., } \\
\text { 2011; Rosenberger \& Kaiser, 1985; } \\
\text { Tähkäpää et al., 2004) }\end{array}$ \\
\hline & Questionnaire/Survey & $\begin{array}{l}\text { (Jaana et al., 2011; Tähkäpää et } \\
\text { al., 2004) }\end{array}$ \\
\hline & Brainstorming & (Frey et al., 2005) \\
\hline & Workshops & (Jaana et al., 2011) \\
\hline & Team Retreat & (Tähkäpää et al., 2004) \\
\hline & Discussion Synthesis & $\begin{array}{l}\text { (Frey et al., 2005; Olsen \& Stead, } \\
\text { 1995; Urbanski et al., 2011) }\end{array}$ \\
\hline & $\begin{array}{l}\text { Describe IT systems and flow of data in graphic format (e.g. flow } \\
\text { diagrams) }\end{array}$ & $\begin{array}{l}\text { (Hutsell \& Mancini-Newell, 2005; } \\
\text { Rosenberger \& Kaiser, 1985) }\end{array}$ \\
\hline & $\begin{array}{l}\text { Use video to describe the continuity of care in different } \\
\text { departmentsww }\end{array}$ & (T. B. Taylor, 2004) \\
\hline \multirow{5}{*}{ Forming the Plan } & Structure Project plan with timelines & (Frey et al., 2005) \\
\hline & $\begin{array}{l}\text { Strategic Planning Methods } \\
\text { - Critical Success Factors } \\
\text { - Value chains } \\
\text { - Strategic alignment }\end{array}$ & (Hevner et al., 2000) \\
\hline & $\begin{array}{l}\text { Gantt Chart to show sequence reflecting technical, resource and } \\
\text { data dependencies }\end{array}$ & (Olsen \& Stead, 1995) \\
\hline & $\begin{array}{l}\text { Order priorities through ranking system from all users with } \\
\text { adjustment from executive }\end{array}$ & (Rosenberger \& Kaiser, 1985) \\
\hline & Create measurable objectives with deliverables & $\begin{array}{l}\text { (Frey et al., 2005; Hutsell \& } \\
\text { Mancini-Newell, 2005; Olsen \& } \\
\text { Stead, 1995) }\end{array}$ \\
\hline \multicolumn{3}{|l|}{ Implementation } \\
\hline Implementation & $\begin{array}{l}\text { Utilize Phase-In training introducing different modules over time } \\
\text { for clinicians }\end{array}$ & (T. B. Taylor, 2004) \\
\hline Reviewing Progress & Use scorecard for assessment to review progress and metrics & $\begin{array}{l}\text { (Hutsell \& Mancini-Newell, 2005; } \\
\text { Mueller et al., 2009) }\end{array}$ \\
\hline \multicolumn{3}{|l|}{ Assessment } \\
\hline \multirow[b]{2}{*}{ Assessment } & Evaluate using measurable objectives formed in the SISP & (Hutsell \& Mancini-Newell, 2005) \\
\hline & $\begin{array}{l}\text { Distribute annual report cards, patient satisfaction survey, market } \\
\text { share reports, quality and performance indicators to staff and } \\
\text { stakeholders }\end{array}$ & (Urbanski et al., 2011) \\
\hline Miscellaneous & $\begin{array}{l}\text { Form and use a Categorized Project Catalog to identify projects } \\
\text { of the same category across different domains (e.g. IT for } \\
\text { scheduling or finance in different departments) }\end{array}$ & (Hutsell \& Mancini-Newell, 2005) \\
\hline
\end{tabular}

Copyright $(C) 2015$, IGI Global. Copying or distributing in print or electronic forms without written permission of IGI Global is prohibited. 
Table 5. Summary of guidelines and factors for success in SISP

\begin{tabular}{|c|c|c|c|}
\hline Area & Guideline & Illustration & Author \\
\hline \multirow{4}{*}{ Stakeholders } & $\begin{array}{l}\text { Open dialogue } \\
\text { between various } \\
\text { end-users }\end{array}$ & $\begin{array}{l}\text { "open dialogue ... encourages participation" } \\
\text { (Urbanski et al., 2011) } \\
\text { "Hearing from all involved stakeholders produces } \\
\text { an objective view of existing issues, and supports } \\
\text { solutions to identified challenges as the project } \\
\text { leads are considered independent and neutral." } \\
\text { (Jaana et al., 2011) }\end{array}$ & $\begin{array}{l}\text { (Jaana et al., 2011; } \\
\text { Urbanski et al., 2011) }\end{array}$ \\
\hline & $\begin{array}{l}\text { Increase } \\
\text { participation of } \\
\text { clinician end-users } \\
\text { (MDs and RNs) } \\
\text { in the planning } \\
\text { process }\end{array}$ & $\begin{array}{l}\text { Involving clinicians enable alignment, as they } \\
\text { can explain how proposed IS will support goals } \\
\text { and strategies. } \\
\text { In hospitals, IM should include not only the } \\
\text { policy makers and systems designers, but also } \\
\text { the future users of HIS applications for increased } \\
\text { acceptance and success } \\
\text { "...too often, an IT strategy is developed without } \\
\text { appropriate involvement of key people outside } \\
\text { the IT function. The plan then is viewed as the IT } \\
\text { function's plan rather than as the organization's } \\
\text { IT strategic plan" (J. Adams, 2005) } \\
\text { "Effective planning must be done by those } \\
\text { individuals who will implement the plans and are } \\
\text { closest to the delivery of care." (Moriarty, 1992) }\end{array}$ & $\begin{array}{l}\text { (J. Adams, 2005; } \\
\text { Hutsell \& Mancini- } \\
\text { Newell, 2005; } \\
\text { Moriarty, 1992; A. } \\
\text { Winter et al., 2000) }\end{array}$ \\
\hline & $\begin{array}{l}\text { Executive/top } \\
\text { management } \\
\text { support }\end{array}$ & $\begin{array}{l}\text { Importance of executive support it is key for } \\
\text { long-term commitment to IT. Top management } \\
\text { ensures necessary resource for IS, and higher } \\
\text { likelihood of alignment }\end{array}$ & $\begin{array}{l}\text { (Bush et al., 2009; } \\
\text { Hutsell \& Mancini- } \\
\text { Newell, 2005) }\end{array}$ \\
\hline & $\begin{array}{l}\text { Importance of } \\
\text { organizational } \\
\text { culture. }\end{array}$ & $\begin{array}{l}\text { "For the integration of IS to be successful, the } \\
\text { conflict between clinicians and administrators is } \\
\text { an important factor with which a hospital must } \\
\text { effective deal." (Kim \& Michelman, 1990) } \\
\text { "Culture and resources influence the success of a } \\
\text { strategy." (J. Adams, 2005) }\end{array}$ & $\begin{array}{l}\text { (J. Adams, 2005; Kim } \\
\text { \& Michelman, 1990) }\end{array}$ \\
\hline \multirow{3}{*}{ Communication } & Avoid IT jargon & $\begin{array}{l}\text { "Use analogies to enhance communication" } \\
\text { (Bush et al., 2009) } \\
\text { "Use every opportunity to educate non-IT } \\
\text { executives about relevant IT-related issues and } \\
\text { subjects." (J. Adams, 2005) }\end{array}$ & $\begin{array}{l}\text { (J. Adams, 2005; Bush } \\
\text { et al., 2009) }\end{array}$ \\
\hline & $\begin{array}{l}\text { Communication } \\
\text { between end-users }\end{array}$ & $\begin{array}{l}\text { "Interviewees expressed that their management } \\
\text { encouraged communication about objectives and } \\
\text { strategies throughout the organization" (Bush et } \\
\text { al., 2009) } \\
\text { "Maintaining communications at several levels } \\
\text { within the health system helped create an } \\
\text { environment of transparency and assured others } \\
\text { that the task force would meet the deadlines for } \\
\text { board review and budget allocation" (Hutsell \& } \\
\text { Mancini-Newell, 2005) }\end{array}$ & $\begin{array}{l}\text { (Bush et al., 2009; } \\
\text { Embi et al., 2005; } \\
\text { Hutsell \& Mancini- } \\
\text { Newell, 2005; } \\
\text { Urbanski et al., 2011; } \\
\text { A. Winter et al., 2000) }\end{array}$ \\
\hline & $\begin{array}{l}\text { End-user } \\
\text { Cooperation }\end{array}$ & $\begin{array}{l}\text { “...increased information systems strategic } \\
\text { planning effectiveness, more responsive and } \\
\text { better designed computing solutions and } \\
\text { more useful end-user training programs were } \\
\text { significant improvements resulting from } \\
\text { organisational cooperation and respect." }\end{array}$ & $\begin{array}{l}\text { (Belkin \& Corbitt, } \\
\text { 2009) }\end{array}$ \\
\hline
\end{tabular}




\section{Table 5. Continued}

\begin{tabular}{|c|c|c|c|}
\hline Area & Guideline & Illustration & Author \\
\hline \multirow{7}{*}{ Planning } & Prioritization & $\begin{array}{l}\text { Demand is greater than resources, prioritize } \\
\text { projects that match values of the organization's } \\
\text { mission }\end{array}$ & $\begin{array}{l}\text { (Rosenberger \& } \\
\text { Kaiser, 1985) }\end{array}$ \\
\hline & $\begin{array}{l}\text { Gradual } \\
\text { development of } \\
\text { SISP }\end{array}$ & $\begin{array}{l}\text { "...strategic planning process should not be } \\
\text { done at one moment in time and put on the } \\
\text { shelf. Rather, it should be continuously tested } \\
\text { and re-visited and modified for changing } \\
\text { business environments and new technologies." } \\
\text { (Gunasekaran \& Garets, 2003) } \\
\text { "Documents should be updated at least yearly... } \\
\text { and progress of various projects in the plan } \\
\text { should be tracked at least monthly." (Spitzer, } \\
\text { 1993) }\end{array}$ & $\begin{array}{l}\text { (Gunasekaran \& } \\
\text { Garets, 2003; Spitzer, } \\
\text { 1993) }\end{array}$ \\
\hline & Integration & $\begin{array}{l}\text { Consider enterprise solution for integrating } \\
\text { information systems as too many one-to-one- } \\
\text { interfaces making situations difficult to manage. }\end{array}$ & $\begin{array}{l}\text { (Altuwaijri, 2011; } \\
\text { Brunskill, 2003) }\end{array}$ \\
\hline & $\begin{array}{l}\text { Differentiation of } \\
\text { Strategic systems } \\
\text { from Support } \\
\text { system }\end{array}$ & $\begin{array}{l}\text { Strategic systems offer a competitive advantage, } \\
\text { not just improved efficiency and effectiveness. } \\
\text { Thus costs should be categorized as direct } \\
\text { business expenses, not as administrative or } \\
\text { overhead expenses. }\end{array}$ & (Moriarty, 1992) \\
\hline & Keep it measurable & $\begin{array}{l}\text { Create research tools amenable to analysis as it } \\
\text { will aid in development and assessment of SISP }\end{array}$ & (Jaana et al., 2011) \\
\hline & $\begin{array}{l}\text { Understand } \\
\text { problems before } \\
\text { trying to solve } \\
\text { them. }\end{array}$ & $\begin{array}{l}\text { "Many participants recognized the identified } \\
\text { challenges for several years and believed they } \\
\text { had the solutions before beginning the strategic } \\
\text { planning process. This may result in force-fitting } \\
\text { predefined solutions. Hence, it is important to } \\
\text { leverage all the information collected to truly } \\
\text { understand the problem within the broader } \\
\text { context and explore alternative solutions." }\end{array}$ & (Jaana et al., 2011) \\
\hline & $\begin{array}{l}\text { Utilize a dynamic } \\
\text { and interactive } \\
\text { plan }\end{array}$ & $\begin{array}{l}\text { "With the realization of this project nearly } \\
\text { every employee can see the goals' statuses and } \\
\text { the project data. This should be an incentive to } \\
\text { document a project's progress promptly, because } \\
\text { otherwise it looks like the project is in delay and } \\
\text { therewith the goal is in danger." }\end{array}$ & (Mueller et al., 2009) \\
\hline \multirow[t]{2}{*}{ Implementation } & $\begin{array}{l}\text { Education of end- } \\
\text { users and clinicians }\end{array}$ & $\begin{array}{l}\text { "A phase-in or modular approach to } \\
\text { implementing the new system allows incremental } \\
\text { learning and adaptation with less impact on } \\
\text { patient care during the transition." (Taylor, 2004) } \\
\text { "Use every opportunity to educate non-IT } \\
\text { executives about relevant IT-related issues and } \\
\text { subjects." (Adams, 2005) }\end{array}$ & $\begin{array}{l}\text { (J. Adams, 2005; Bush } \\
\text { et al., 2009; T. B. } \\
\text { Taylor, 2004) }\end{array}$ \\
\hline & $\begin{array}{l}\text { Commitment to the } \\
\text { Timeline }\end{array}$ & $\begin{array}{l}\text { "Set strong agendas, timelines, and guidelines } \\
\text { for the planning process...initial faltering of } \\
\text { the work team in developing the initial strategic } \\
\text { framework further reinforced the need for the } \\
\text { team's leaders to provide steady, measured, and } \\
\text { consistent pressure to deliver results." }\end{array}$ & (Frey et al., 2005) \\
\hline
\end{tabular}


Table 5. Continued

\begin{tabular}{|c|c|c|c|}
\hline Area & Guideline & Illustration & Author \\
\hline \multirow{4}{*}{ Foresight } & $\begin{array}{l}\text { Prepare for } \\
\text { projected } \\
\text { requirements }\end{array}$ & $\begin{array}{l}\text { "Each institution should examine its strategic } \\
\text { business and IS plans, paying special attention } \\
\text { to the current and projected managed care } \\
\text { requirements, and modify the plans according to } \\
\text { anticipated needs." (Ribka, 1996) }\end{array}$ & $\begin{array}{l}\text { (Brunskill, 2003; } \\
\text { Hevner et al., 2000; } \\
\text { Ribka, 1996) }\end{array}$ \\
\hline & Risk Management & $\begin{array}{l}\text { "[Managing technology risk is] critical to the } \\
\text { success of hospital's strategy as the management } \\
\text { of business risk." (Henderson \& Thomas, 1992) } \\
\text { "... implementation of large Information systems } \\
\text { is considered complex and risky exercise... be } \\
\text { ready for this journey by learning about the risks } \\
\text { associated with IT projects." (Altuwaijri, 2011) }\end{array}$ & $\begin{array}{l}\text { (Altuwaijri, 2011; } \\
\text { Henderson \& Thomas, } \\
\text { 1992; Spitzer, 1993) }\end{array}$ \\
\hline & $\begin{array}{l}\text { Prepare for } \\
\text { uncertainties }\end{array}$ & $\begin{array}{l}\text { "Management uncertainties have increased with } \\
\text { lack of predetermined guidelines needed to } \\
\text { respond to these interactions. A well-founded SIS } \\
\text { will provide flexibility and quick information } \\
\text { necessary for hospitals to make good decisions." } \\
\text { (Killingsworth et al., 2006) } \\
\text { "Develop IT strategy alternatives. Multiple } \\
\text { business scenarios must be evaluated and the IT } \\
\text { strategy must take into account shifting market } \\
\text { uncertainties." (Brigl et al., 2005) } \\
\text { "The strategic plan should enable graceful } \\
\text { growth rather than unanticipated obsolescence } \\
\text { of the organization's technical infrastructure." } \\
\text { (Spitzer, 1993) }\end{array}$ & $\begin{array}{l}\text { (Brigl et al., 2005; } \\
\text { Killingsworth et al., } \\
\text { 2006; Spitzer, 1993) }\end{array}$ \\
\hline & $\begin{array}{l}\text { Consider } \\
\text { alternative } \\
\text { solutions }\end{array}$ & $\begin{array}{l}\text { "Define, evaluate, and present alternatives. } \\
\text { Almost always, there is more than one possible } \\
\text { solution. By presenting and evaluating } \\
\text { alternatives to the executives, they are able to } \\
\text { make a more informed decision and support that } \\
\text { decision when questions or objections arise." (J. } \\
\text { Adams, 2005) }\end{array}$ & $\begin{array}{l}\text { (J. Adams, 2005; } \\
\text { Gunasekaran \& Garets, } \\
\text { 2003) }\end{array}$ \\
\hline
\end{tabular}

\section{Table 6. Summary}

\begin{tabular}{|l|l|}
\hline $\begin{array}{l}\text { What was } \\
\text { already known } \\
\text { on the topic }\end{array}$ & $\begin{array}{l}\text { - The success of information systems depend on the extent to which healthcare organizations } \\
\text { consider objectives and strategies in their information planning process; } \\
\text { - There is limited information available in the literature on methodologies, frameworks and } \\
\text { best practices in strategic information system planning in the healthcare sector. }\end{array}$ \\
\hline $\begin{array}{l}\text { What this study } \\
\text { added to our } \\
\text { knowledge }\end{array}$ & $\begin{array}{l}\text { - Identify demographic trends; } \\
\text { - Identify topics of SISP covered in the literature; } \\
\text { - Assemble a set of tools to develop, implement and assess the plan; } \\
\text { - Assemble a set of guidelines in order to aid researchers and practitioners alike. }\end{array}$ \\
\hline
\end{tabular}


plan, as well as (iv) a set of guidelines in order to aid researchers and practitioners alike. SISP in healthcare is still a small but growing field of research. This paper highlights findings from the literature on the SISP tools, guidelines and lessons-learned for SISP in healthcare. Some of these highlights have often been adopted from non-healthcare industries and found to be particularly applicable in healthcare settings. Such highlights from the literature, which were of particular importance to healthcare industries, can aid IS practitioners in future implementation of health information systems.

SISP is a permanent task for an organization, its life spans so far as the timeline of the plan, and it must be monitored and assessed. The life cycle of SISP, which cycles through three broad stages of development, implementation, and assessment before must be revised to meet the changing internal and external environment. The papers included in this study indicate the average development process up to the preimplementation stage to have occurred over a 6-month time period. The plans themselves were on average to be valid for a period of 3 to 5 years. Over its lifespan, the SISP can require improvements or revisions given changing circumstances in either internal or external environments of the organization. For this reason a flexible, dynamic SISP is preferred over a static one (Killingsworth et al., 2006; Mueller et al., 2009) such that an organization can adapt to changing environments and stay on course to achieve the ideal state.

The development stage is comprised of evaluating the current state of the organization, envisioning an ideal state aligned with the overall organization strategy, analyzing the gap to be closed through steps described in the strategic plan. Once the plan is approved, it will be implemented in the organization, with the deployment of projects and strategies according to the timeline. It is important to assess the progress of the plan throughout the implementation, and also conduct a final assessment at the end of the plan's life cycle.

Practitioners look for guidelines and standard procedures for developing plans. However there appears to be a lack of consensus on best practices and standardized procedures in the literature for SISP development in healthcare organizations. This study sought to synthesize the available information on SISP in healthcare organizations. As such, our research can serve to equip healthcare managers and other stakeholders who seek to develop their own SISPs in four ways:

1. The taxonomy of papers provided in table 3 enables practitioners to find literature relevant to their status quo in the process of SISP. In this paper, the literature on SISP in healthcare have been compiled to aid those who are seeking information on topics of SISP development, SISP Guidelines, SISPAssessment and tools for SISP to find appropriate papers more easily. This table also outlines the context and summary of each of the papers included in the literature review;

2. We provide a 'toolbox' for practitioners who are developing, utilizing or assessing SISP. We have compiled a set of tools that can be used at various stages throughout the SISP life cycle. Decision makers and stakeholders alike may find this set of tools helpful in their own SISP efforts, and may refer to it in creating their own SISP;

3. Lastly, we have outlined important guidelines for development, implementation and evaluation of SISP for health, which have fostered or hindered the success of SISP in other organizations. Practitioners can use this assembly of guidelines to become well aware of the lessons learned from others' past experiences. The guideline provides a set of recommendations for consideration in areas concerning stakeholders, communication, planning, implementation and foresight necessary for successful SISPs. Practitioners should note that SISP will be advantageous not only as a roadmap for implementing IS (Olsen \& Stead, 1995), but also to leverage ongoing investments and aid in communicating with many of 
the stakeholders involved in complex healthcare organizations.

\section{CONCLUSION}

Information technologies have made numerous advancements to people's life (Ghapanchi et al., 2012a; Ghapanchi et al., 2012b; Ghapanchi et al., 2013; Ghapanchi and Aurum, 2011a). Several research have been conducted on various areas of IT (Ghapanchi et al., 2008; Ghapanchi and Aurum, 2011b; Ghapanchi and Aurum, 2012a; Ghapanchi and Aurum, 2012b; Ghapanchi et al., 2011) including strategic IS planning. Whereas there is a thin body of knowledge which provide an overview on the existing studies on SISP (e.g. Amrollahi and Ghapanchin 2013; Amrollahi and Ghapanchin 2014), there is a lack in research that overviews the application of SISP in healthcare.

Hundreds of billions of dollars are being spent on bettering IS in healthcare organizations to achieve better quality of care. As IT becomes increasingly crucial in healthcare delivery, SISP will further be instrumental in implementing information technology seamlessly with health organizations' goals and objectives. However, there is currently a shortage the literature of research for SISP in the healthcare industry. This gap poses a challenge to health practitioners wishing to implement SISP in their own organizations. To fill this gap, we conducted a systematic literature review of 42 papers in the literature from 1985 to 2011 to provide an overall illustration of the work that has been conducted in SISP in healthcare to the readers. We investigated five research questions (i) identifying demographic trends, (ii) identifying topics of SISP covered in the literature, (iii) assembling a set of tools to develop, implement and assess the plan, as well as (iv) a set of guidelines in order to aid researchers and practitioners alike. Through a holistic presentation of SISP in healthcare as well as further gaps in the literature introduced in this paper, we hope to guide future studies towards a deeper comprehension of SISP in healthcare. See Table 6 for a summary table of our findings.

\section{LIMITATION}

It should be noted that the results of this study are based on the information gathered from the literature. Hence, the validity threats to, and limitations of, our reference papers may also apply to this research. We also acknowledge that although this research provides a synthesis of SISP procedure, it doesn't cover impact of the variable elements in the process. This limitation also originates from the fact that the selected papers for our systematic review have not covered this issue.

Although we have undertaken a thorough literature review of SISP in healthcare industry organizations, we note that with the increasing number of studies on the topic, we cannot guarantee to have taken into account all the references in this area. Another concern is that few studies have been carried out on SISP in healthcare in Asian, African and South American countries, suggesting we cannot present a global view of this area. There are biases and limitations associated with the studies reviewed, including methodological quality, measurement quality and variability, limited description of the SISP interventions, varying psychometric quality of measurement instruments for the primary outcome(s), limited assessment of effectiveness, and lack of clarity of outcomes assessed, and limited duration of the studies.

As evidenced by the limited literature reviewed in this paper, the term 'strategic information systems planning' and its various alternates are not in widespread use in the literature. Thus this paper was not able to account for work in cognate areas, such as IS for health care in developing countries that have strategic concerns and links IS to health planning, or UK government's National Programme for Information Technology (NPfIT), and other literature from various journals which did not meet the search criteria but still pertained to IS. 


\section{REFERENCES}

Adams, B., Berner, E. S., \& Wyatt, J. R. (2004). Applying Strategies to Overcome User Resistance in a Group of Clinical Managers to a Business Software Application. Journal of Organizational and End User Computing, 16(4), 55-64. doi:10.4018/ joeuc. 2004100104

Adams, J. (2005). Successful strategic planning: Creating clarity. Journal of Healthcare Information Management : JHIM, 19(3),24-31.PMID:16045081

Agarwal, R., Gao, G., DesRoches, C., \& Jha, A. K. (2010). Research Commentary - The Digital Transformation of Healthcare: Current Status and the Road Ahead. Information Systems Research, 21(4), 796-809. doi:10.1287/isre.1100.0327

Altuwaijri, M. (2011). Health Information Technology Strategic Planning Alignment in Saudi Hospitals: A Historical Perspective. Journal of Health Informatics in Developing Countries, 5(2), 18.

Ammenwerth, E., Buchauer, A., \& Haux, R. (2002). A requirements index for information processing in hospitals. Methods of Information in Medicine, 41(4), 282-288. Retrieved from http://www.scopus. com/inward/record.url?eid=2-s2.0-0036397671\&pa rtnerID $=40 \&$ md5 $=\mathrm{d} 36955 \mathrm{a} 1389892800289 \mathrm{a} 402 \mathrm{~d} 6$ eaad88 PMID: 12425239

Amrollahi, A., Ghapanchi, A. H., \& Najaftorkaman, M. (2014). A generic framework for developing strategic information system plans: Insights from past three decades. Paper presented at the 18th Pacific Asia Conference on Information Systems, Chengdu, China.

Amrollahi,A., Ghapanchi,A. H., \& Talaei-Khoei,A. (2013). A systematic literature review on strategic information systems planning: Insights from the past decade. Pacific Asia Journal of the Association for Information Systems, 5(2), 39-66.

Austin, C. J., Hornberger, K. D., \& Shmerling, J. E. (2000). Managing information resources: A study of ten healthcare organizations. Journal of Healthcare Management, 45(4), 229-239. Retrieved from http:// www.scopus.com/inward/record.url?eid=2-s2.0$0033911822 \&$ partnerID $=40 \&$ md5 $=17 \mathrm{c} 9 \mathrm{ae} 3 \mathrm{~b} 4 \mathrm{f} 90$ b644d38d8ddc44da61d9 PMID:11067415

Beale, T. (2005). The Health Record - why is it so hard? In IMIA Yearbook of Medical Informatics (pp. 301-304).
Belkin, M., \& Corbitt, B. (2009). The assessment of information systems effectiveness in private and hospital pathology. Business Information Technology. RMIT University.

Borovits, I., Taussig, I., \& Yeheskel, O. (1989). Strategic information systems planning for national public health services in Israel. Proceedings of the Hawaii International Conference on System Science, 4,357-365. Retrieved from http://www.scopus.com/ inward/record.url?eid=2-s2.0-0024859616\&partnerI $\mathrm{D}=40 \& \mathrm{md} 5=365 \mathrm{ac} 3 \mathrm{ebc} 3949909 \mathrm{ca} 6 \mathrm{~b} 056 \mathrm{df} 10452 \mathrm{~b} 7$

Bricknall, R., Darrell, G., Nilsson, H., \& Pessi, K. (2007). Aligning IT Strategy with Business Strategy through the Balanced Scorecard in a multinational pharmaceutical company (pp. 235b-235b). IEEE. doi:10.1109/HICSS.2007.53

Brigl, B., Ammenwerth, E., Dujat, C., Gräber, S., Grosse, A., \& Häber, A. et al. (2005). Preparing strategic information management plans for hospitals: a practical guideline SIM plans for hospitals: a guideline. International Journal of Medical Informatics, 74(1), 51-65. doi:10.1016/j.ijmedinf.2004.09.002 PMID: 15626636

Brunskill, I. (2003). Building a Quality Improvement Coalition: A Cancer Information Management Strategy for Ontario. ElectronicHealthcare, 2(2), 7.

Bush, M., Lederer, A. L., Li, X., Palmisano, J., \& Rao, S. (2009). The alignment of information systems with organizational objectives and strategies in health care. International Journal of Medical Informatics, 78(7), 446-456. doi:10.1016/j.ijmedinf.2009.02.004 PMID:19307148

Canadian Institute for Health Information. (2009). [A decade in review]. Health Care in Canada, 2009.

Chiasson, M. W., \& Davidson, E. (2004). Pushing the contextual envelope: Developing and diffusing IS theory for health information systems research. Information and Organization, 14(3), 155-188. doi:10.1016/j.infoandorg.2004.02.001

Embi, P., Jung, Y. H., Schneider, D., Sofsky, J., Sundre, M., \& Yackel, T. ... Ball, M. J. (2005). Strategic Informatics: Planning for the Future of AtlanticHealth. In N. M. Lorenzi, J. S. Ash, J. Einbinder, W. McPhee, \& L. Einbinder (Eds.), Transforming Health Care Through Information (2nd ed.). New York, NY: Springer Science and Business Media, Inc. 
European Commission, \& Reding, V.(2009). EU: The European Files - eHealth inEurope. (E. Commission, Ed.)Creating a European Health Market Based on ICT. EU: Les Dossiers Europeans. Retrieved from http://www.epractice.eu/files/The European Files eHealth in Europe - EN.pdf

Fichman, R., Kohli, R., \& Krishnan, R. (2011). Editorial Overview-The Role of Information Systems in Healthcare: Current Research and Future Trends. Information Systems Research, 22(3), 419-428. http://pubsonline.informs.org/doi/abs/10.1287/ isre. 1110.0382 ? journalCode=isre doi:10.1287/ isre. 1110.0382

Frey, K., Cranmer, J. J., Kirby, L. J., Lenko, P. H., \& Vrabel, A. Z. (2005). The Development and Implementation of a Strategic and Tactical Planning Framework at Mayo Clinic Arizona. Journal of Healthcare Information Management, 19(3), 8. Retrieved from http://www.ncbi.nlm.nih.gov/ pubmed/16045083 PMID:16045083

Gauld, R. (2007). Public sector information system project failures: Lessons from a New Zealand hospital organization. Government Information Quarterly, 24(1), 13. doi:10.1016/j.giq.2006.02.010

Ghapanchi,A.H., \&Aurum,A. (2011a).Antecedents to IT personnel's intentions to leave: A systematic literature review. Journal of Systems and Software, 84(2), 238-249. doi:10.1016/j.jss.2010.09.022

Ghapanchi, A. H., \& Aurum, A. (2011b). Measuring the effectiveness of the defect-fixing process in open source software projects. Proceedings of the 44th Hawaii International Conference on System Sciences, Hawaii, US. doi:10.1109/HICSS.2011.305

Ghapanchi,A.H., \&Aurum,A. (2012a).Competency rallying in electronic markets: Implications for open source project success. Electronic Markets, 22(2), 117-127. doi:10.1007/s12525-012-0088-0

Ghapanchi,A.H., \& Aurum, A. (2012b). The impact of project capabilities on project performance: Case of open source software projects. International Journal of Project Management, 30(4), 407-417. doi:10.1016/j.ijproman.2011.10.002

Ghapanchi, A.H., Aurum, A., and Daneshgar, F. (2012a). The Impact of Process Effectiveness on User Interest in Contributing to the Project, Journal of software, 7(1), 212-219.

Ghapanchi, A. H., Aurum, A., \& Low, G. (2011). Creating a measurement taxonomy for the success of open source software projects. First Monday, 16(8). doi:10.5210/fm.v16i8.3558
Ghapanchi, A. H., Khakbaz, M. H., \& Jafarzadeh, M. H. (2008). An application of data envelopment analysis (DEA) for ERP system selection: Case of a petrochemical company. International Conference on Information Systems, France, Paris.

Ghapanchi, A. H., Tavana, M., Khakbaz, M. H., \& Low, G. (2012b). A Methodology for Selecting Portfolios of IS/IT Projects with Interactions and Under Uncertainty. International Journal of Project Management, 30(7), 791-803. doi:10.1016/j.ijproman.2012.01.012

Ghapanchi, A. H., Wohlin, C., \& Aurum, A. (2013). Resources contributing to gaining competitive advantage for open source software projects: An application of resource-based theory. International Journal of Project Management, 32(1), 139-152. doi:10.1016/j.ijproman.2013.03.002

Gunasekaran, S., \& Garets, D. E. (2003). Business value of IT: The strategic planning process. Journal of Healthcare Information Management: JHIM, 17(1), 31-36. PMID:12553218

Hasselbring, W., Peterson, R., Smits, M., \& Spanjers, R. (2000). Strategic information management for a Dutch university hospital. Studies in Health Technology and Informatics, 77, 885-889. Retrieved from http://www.ncbi.nlm.nih.gov/pubmed/11187681 PMID:11187681

Heeks, R. (2006). Health information systems: Failure, success and improvisation. International Journal of Medical Informatics, 75(2), 13. doi:10.1016/j. ijmedinf.2005.07.024 PMID:16112893

Henderson, J. C., \& Thomas, J. B. (1992). Aligning business and information technology domains: Strategic planning in hospitals. Hospital \& Health Services Administration, 37(1), 71-87. PMID:10116114

Hevner, A. R., Berndt, D. J., \& Florida, S. (2000). Strategic information systems planning with box structures (Vol. 00, p. 11 pp. vol. 1). IEEE.

Hutsell, R., \& Mancini-Newell, L. (2005). Information technology strategic planning: Art or science? Journal of Healthcare Information Management : JHIM, 19(3), 32-38. Retrieved from http://www.ncbi. nlm.nih.gov/pubmed/16045082 PMID:16045082

Iacovou, C. L. (1999). The IPACS project: When IT hits the fan. Journal of Information Technology, 14(3), 267-275. doi:10.1080/026839699344566 
Jaana, M., Teitelbaum, M., \& Roffey, T. (2011). IT strategic planning in a pediatric hospital: Overview of the process and outcomes. In Proceedings of the Annual Hawaii International Conference on System Sciences (pp. 2910-2919). Ieee. doi:10.1109/ HICSS.2012.395

Killingsworth, B., Newkirk, H. E., \& Seeman, E. (2006). An integrative health information systems approach for facilitating strategic planning in hospitals. Health Care Management Review, 31(2), 119-129. http://www.ncbi.nlm.nih. gov/pubmed/16648691 doi:10.1097/00004010200604000-00005 PMID:16648691

Kim, K. K., \& Michelman, J. E. (1990). An Examination of Factors for the Strategic Use of Information systems in the Healthcare Industry. Management Information Systems Quarterly, 14(2), 16. doi: $10.2307 / 248778$

Kitchenham, B. (2004). Procedures for Performing Systematic Reviews.

Kitchenham, B., Pearl Brereton, O., Budgen, D., Turner, M., Bailey, J., \& Linkman, S. (2009). Systematic literature reviews in software engineering - A systematic literature review. Information and Software Technology, 51(1), 7-15. doi:10.1016/j. infsof.2008.09.009

Moriarty, D. D. (1992). Strategic information systems planning for health service providers. Health Care Management Review, 17(1), 85-90. doi:10.1097/00004010-199201710-00011 PMID:1548123

Mueller, U., Issler, L., Funkat, G., \& Winter, A. (2009). An interactive strategic information management plan to integrate strategic and tactical information management in hospitals. In Proceedings of the 2009 ICSE Workshop on Software Engineering in Health Care (pp. 12-19). SEHC; Retrieved from http://www.scopus.com/inward/record.url?eid=2s2.0-70349902791\&partnerID $=40 \& \mathrm{md} 5=\mathrm{de} 70$ 1a46c61de8256b405d99749de863 doi:10.1109/ SEHC.2009.5069601

OECD. (2011). Health at a Glance 2011 - OECD Indicators. Retrieved from http://www.oecd-ilibrary. org/social-issues-migration-health/health-at-aglance-2011_health_glance-2011-en

Olsen, A. J., \& Stead, W. W. (1995). Strategic planning for information management: what are the deliverables? Proceedings/the... Annual Symposium on Computer Application [sic] in Medical Care. Symposium on Computer Applications in Medical Care, 785-789.
Ribka, J. P. (1996). Strategic planning for managed care information systems. Health Management Technology, 17(12), 30, 32, 55. PMID:10162132

Rosenberger, H. R., \& Kaiser, K. M. (1985). Strategic planning for health care management information systems. Health Care Management Review, 10(1), 7-17. doi:10.1097/00004010-198501010-00002 PMID:3905710

Science Watch. (2009). Top 20 Countries in ALL FIELDS, 1999-August 31, 2009. Retrieved from http://archive.sciencewatch.com/dr/ cou/2009/09decALL/

Smith, J. (1995). The strategic planning of health management information systems. Australian Health Review : A Publication of the Australian Hospital Association, 18(4), 26-42.

Snyder-Halpern, R., \& Chervany, N. L. (2000). A clinical information system strategic planning model for integrated healthcare delivery networks. The Journal of Nursing Administration, 30(12), 583-591. http://www.ncbi.nlm.nih. gov/pubmed/11132346 doi:10.1097/00005110200012000-00009 PMID:11132346

Spitzer, P. G. (1993). A comprehensive framework for I/S strategic planning. Computers in Healthcare, 14(5), 28, 30-33. PMID:10125576

Stead, W. W. (1988). Information management through integration of distributed resources. Bulletin of the Medical Library Association, 76(3), 242-247. PMID:3416101

Tähkäpää, J., Box, P. O., Turku, F. I. N., \& Tahkapaa, J. (2004). Increasing role of information systems in public health care-Challenge to the management. In Proceedings of the Hawaii International Conference on System Sciences (Vol. 37, pp. 2235-2244). Retrieved from http://www.scopus.com/inward/record. url? eid=2-s2.0-12344294463\&partnerID=40\&md5 $=9 \mathrm{f} 5 \mathrm{e} 79 \mathrm{~cd} 5 \mathrm{cbca} 0 \mathrm{adb} 3 \mathrm{~b} 1 \mathrm{f} 30 \mathrm{cff} 2 \mathrm{a} 0 \mathrm{~b} 17$

Taylor, R., Bower, A., Girosi, F., Bigelow, J., Fonkych, K., \& Hillestad, R. (2005). Promoting Health Information Technology: Is There A Case For More-Aggressive Government Action? Health Affairs, 24(5), 1234-1245. doi:10.1377/ hlthaff.24.5.1234 PMID:16162568

Taylor, T. B. (2004). Information management in the emergency department. Emergency Medicine Clinics of North America, 22(1), 241-257. doi:10.1016/ S0733-8627(03)00093-2 PMID:15062508 
Tolchin, S. G. (1986). Overview of an architectural approach to the development of the Johns Hopkins Hospital distributed clinical information system. Journal of Medical Systems, 10(4), 321-338. doi:10.1007/BF00992434 PMID:3783061

Urbanski, J., Baskel, M., \& Martelli, M. (2011). Strategic planning--a plan for excellence for South Haven Health System. Nursing Administration Quarterly, 35(3), 227-234. doi:10.1097/ NAQ.0b013e3181ff39ef PMID:21654482

Van De Wetering, R., Batenburg, R., \& Lederman, R. (2010). Evolutionistic or revolutionary paths? A PACS maturity model for strategic situational planning. International Journal of Computer Assisted Radiology and Surgery, 5(4), 401-409. doi:10.1007/ s11548-010-0414-y PMID:20379793

Walker, D. W., \& Houston, F. S. (2004). Developing a Strategic Information Systems Plan for the Heidelberg US Army Medical Department Activity, 298(07040188).

Winter, A., Brigl, B., Buchauer, A., Dujat, C., Graber, S., \& Hasselbring, W. et al. (2000). Purpose and structure of strategic plans for information management in hospitals. Studies in Health Technology and Informatics, 77, 880-884. PMID:11187680
Winter, A., Brigl, B., \& Wendt, T. (2003). Modeling Hospital Information Systems (Part 1): The Revised Three-layer Graph-based Meta Model 3LGM2. Methods of Information in Medicine, 42(5), 544-551. Retrieved from http://www.scopus.com/inward/ record.url?eid=2-s2.0-0346964654\&partnerID= 40\&md5=0d820aa41e7504b92bfa6454da5c4d07 PMID:14654889

Winter, A. F., Ammenwerth, E., Bott, O. J., Brigl, B., Buchauer, A., \& Graber, S. et al. (2001). Strategic information management plans: The basis for systematic information management in hospitals. International Journal of Medical Informatics, 64(23), 99-109. doi:10.1016/S1386-5056(01)00219-2 PMID:11734379

Yap, G. A., Platonova, E. A., \& Musa, P. F. (2006). Use of information systems in Air Force medical treatment facilities in strategic planning and decisionmaking. Journal of Medical Systems, 30(1), 9-16. doi:10.1007/s10916-006-7398-8 PMID:16548409 
Theresa Lee is a doctoral student at the University of Toronto's Institute of Health Policy, Management and Evaluation (Canada) where she also completed her Masters of Health Informatics. She currently works at the Centre for Global eHealth Innovation at Toronto General Hospital where she project manages the design, development and evaluation of consumer mobile ICT to improve quality of care for chronic disease patients. She was the recipient of Canada's Health Informatics Association's National Student Innovation Award for her research in population eHealth. She is interested in how information systems play a role in developing equitable and sustainable healthcare systems.

Amir Hossein Ghapanchi is a tenured faculty member at the School of Information and Communication Technology, Griffith University, Australia. Prior to that he has worked at University of Technology Sydney and the University of New South Wales (UNSW). He obtained his PhD in Information Systems from the University of New South Wales (UNSW), Australia. Amir has also been an active member of the Institute for Integrated Intelligent Systems (IIIS) and Asia-Pacific ubiquitous Healthcare Research Centre (APuHC). Dr Ghapanchi is a section editor for Australasian Journal of Information System, and an associate editor for International Journal of Enterprise Information Systems, and International Journal of Strategic Decision Sciences. Amir has published over 50 referred publications including 40 journal articles in prestigious information systems and management journals such as Information and Organization, Journal of the Association for Information Science and Technology (JASIST), Electronic Markets, Journal of Medical Internet Research, Journal of Computer and System Sciences, International Journal of Project Management, Journal of Systems and Software, and International Journal of Information Management. Amir has been in receipt of several internal/external research and $L \& T$ grants.

Amir Talaei-Khoei is a faculty member at the University of Technology, Sydney (UTS) where he coordinates an international initiative for Adoption of Assistive Technologies in Aged Care involving several universities, research institutes and industrial partners. Since 2008, he has been an active member of Asia-Pacific ubiquitous Healthcare Research Centre (APuHC). Dr Talaei-Khoei is a member of editorial boards for Australasian Journal of Information Systems and Health Informatics. He presently serves as an executive in Australian Association of Information Systems (AAIS). Amir's research interests lie in the area of health informatics, ranging from theoretical applications of agent-based contextual awareness in complex and wicked healthcare problems to adoption and management of technologies in healthcare and aged care settings. Dr Talaei-Khoei received his PhD from the University of New South Wales (UNSW) in Australia and holds a MSc of Information Technology from the Royal Institute of Technology (KTH) in Sweden.

Pradeep Ray is the Director of the WHO Collaborating Centre on eHealth at the University of New South Wales, Australia. He is the founder of the Asia-Pacific ubiquitous Healthcare Research Centre (APuHC) aimed at conducting multi-disciplinary research on the development and evaluation of ubiquitous healthcare using emerging technologies, such as the mobile broadband communication technologies. APuHC has been involved in several international initiatives on the application of mHealth, such as in Indonesia, Bangladesh, PNG and India. Pradeep Ray, currently an IEEE Distinguished Lecturer on eHealth, has been the Chair of the IEEE Technical Committee on eHealth (eHealthTC) and the founder of IEEE Healthcom that is now the forum of discussions for the IEEE/ITU-D/WHO initiatives on e-Health and m-Health. 


\section{APPENDIX}

\section{Demography}

Year:

Country:

Source Type:

Source Name:

\section{Research Method}

\section{Research Type}

$\square$ Empirical

$\square$ Qualitative

$\square$ Quantitative

$\square$ Theoretical/Practical

\section{Research Method}

$\square$ Case Study

$\square$ Literature Review

$\square$ Survey

$\square$ Interview

$\square$ Focus Group

$\square$ Action Research

$\square$ Delphi

$\square$ Document Analysis

$\square$ Other:

$\square$ N/A (Non-Empirical)

\section{Key Results}

\section{Topic of SISP}

$\square$ Development of SISP

$\square$ Guidelines for SISP

$\square$ Assessment of SISP

$\square$ Tools for SISP

Notes: 